\title{
NATIONAL AND REGIONAL CHARACTERISTICS OF UNEMPLOYMENT IN SERBIA
}

\section{A MUNKANÉLKÜLISÉG NEMZET- ÉS REGIONÁLIS-GAZDASÁGI SAJÁTOSSÁGAI SZERBIÁBAN}

\author{
Zoltán Takács, doktor-jelölt \\ Pécsi Regionális Politika és Gazdaságtan Doktori Iskola, \\ Regionális Tudományi Társaság Szabadka. \\ Address: $\quad 24420$ Magyarkanizsa, Sumádia utca 31. \\ Tel: $\quad$ 063-16-19-118 \\ 062-27-28-45 \\ E-mail: $\quad$ takacszoli@stcable.rs
}




\title{
NATIONAL AND REGIONAL CHARACTERISTICS OF UNEMPLOYMENT IN SERBIA
}

\section{A MUNKANÉLKÜLISÉG NEMZET- ÉS REGIONÁLIS-GAZDASÁGI SAJÁTOSSÁGAI SZERBIÁBAN}

Kulcsszavak: munkanélküliség, tranzíció, regionális egyenlőtlenségek, regionális foglalkoztatáspolitika

\begin{abstract}
Kivonat
Szerbia 2009-ben, az átmeneti időszak majdnem teljes lezárását követően kétszámjegyű munkanélküliségi rátát tesz a tranzíció sikerének mérlegére. A munkanélküliség csökkentése, illetve a foglalkoztatás növelése általános stratégiai fejlesztési prioritás kell, hogy legyen, a gazdasági reformok, az általános gazdasági légkör, és a külföldi tőkebefektetések problémájának integrált megoldásával. A gazdasági aktivitások felülvizsgálata során egy új társadalom-gazdasági formáció kialakulása közben, nélkülözhetetlen a gazdasági térszerkezet változásaiból kiindulni. Az Európai integrációs távlatok a hazai termelés és versenyképesség további kérdéseit vetik föl. Kétségtelen, hogy a szerkezeti munkanélküliség jelei a munakerőpiac mind erősebb behatásai miatt egyre kifejezettebbek, ugyanis a munkaerő iránti kereslet és kínálat nem találkozik egymással. Országunk EUs ambícióit mérlegelve, a Schengen-t követő időszakban feltételezhetjük, hogy a munkaerőmobilitás növekedni fog, emigrációs motívumok is meg fognak jelenni. Kiegészítő - túlélési megoldásként megmarad a feketegazdaság.

Határozott bizonyítást nyer a tény, hogy a foglalkoztatás, munkanélküliség problémája csak is regionális és lokális szinteken tud hatékony megoldásokat felmutatni, mégsem történik valós regionális-lokális érdekérvényesítés. Ennek oka a hatásköri, decentralizált hatalmi struktúra hiánya, ahol továbbra is a központi hatalmi szerv delegálásával történnek (a lokális szintek felé idézett) különböző foglalkoztatáspolitikai intézkedések.
\end{abstract}

Keywords: employment, process of transition, regional differences, regional employment policy

\section{Extended Abstract in English}

The existence of market (so the labour market) forms the natural systematic environment that ensures improving economic effectiveness. Over developing market economy the number of employees has been decreasing in every former socialist country, as a natural consequence. With the ceasing of the former socioeconomic order - which ignored economic rationality, capital accumulation, productivity and national/international competitiveness - many unreasonable jobs have disappeared. The market is effectively sanctioning the phenomenon of latent unemployment, making it to serve profit earning. Transition to market economy is painful, causing huge transitional costs and requires waiver from the inhabitants.

Employment and unemployment (together with its current economic and social consequences) are indicators of the process, dynamics and quality of transition. Transitional countries on the Balkans first experienced the emerging decrease of production at the beginning of the 1990's. National income per capita automatically reordered the ranking of these countries. The number of employees in private companies (especially in micro companies) is constantly increasing, while the number of those in state-owned economic subjects is slowly but continuously decreasing. Flexible forms of employment (part-time job, self-employment etc.) are essentially not present in Serbian labour market.

The phenomenon of emigration and black economy are the following processes in these transformations. The past twenty years can be characterized by intensive emigration of the population mainly towards welfare states (temporarily employed abroad, brain drain, brain flight) due to problems of unemployment, low wages, and economic and political crisis. According to estimates there are 2.5 million (others say four million) Serbians or people with Serbian origins who live outside of Serbia. This can be explained either by development level of the region, its regional identity or autonomy. Maybe the biggest challenge for employment policy in transition countries is the problem of black economy. According to the World Bank's report from $200643 \%$ of all employees are in the non-official sector, and $26.7 \%$ of people are illegally employed at employers. 
One example of inequality in Serbia is discrimination in the world of work based on gender. It can be also found ethnic-based inequalities at the labour market of Serbia. There is also inequality based on the place of origin (village or town) concerning willingness for further training, and in employment. Refugees have worsened the problem of unequal opportunities since their official number reached 303,769 in 2007, while $27.9 \%$ of them were unemployed.

In an European comparison the employment rate of active population in Serbia (51\%) is low, otherwise the unemployment rate is very high in region of neighboring countries (16\%). Focus on the group of unemployed, there is a huge proportion of people with secondary school qualifications and young people. About $50 \%$ of all unemployed are form the active population younger than 34. In 2009 loss of employment was the most drastic in the following business sectors: processing industry $23 \%$, trade $23 \%$, education $15 \%$, real estate $9 \%$, construction 6\%, transport and catering industry $4-4 \%$.

Examples from the European Union also show that there is no universal receipt for resolving the problem of unemployment. Member countries have to strive to create and permanently keep up flexibility of labour market, so with this to provide better work and life conditions to their citizens. Employment is the best form of social integration, which is among the EU priorities for the 21Pst century.

In a macro - regional comparison the employment and unemployment indicators of Vojvodina are less favorable in all respects. The activity rate is $2.2 \%$ below the rate in Central Serbia. The employment rate is $1.7 \%$ lower than the employment rate in Central Serbia. Unemployment is higher in Vojvodina compared to both Serbia and Central Serbia, being 15.8\%. Because of these facts the possibilities of regional development have to be considered.

Regional development in Serbia faces enormous regional differences. In general, the causes of differences are the underdeveloped infrastructure, lack of qualified human capital and lack of entrepreneurial spirit. An important idea points out the necessity of increased labour mobility within the region, since this way the strict structure of the regional labour market may become flexible. According to the Serbian Regional Development Strategy every region (district) has to define its on toolset of employment policy in tune with the needs specific to that region and in order to improve employment opportunities and increase employment in the region. However, because of centralized financial authority, actions of regional employment policy are impossible to realize over the current competition system of central authorities. Employment policy measures may be effective at regional level over delegating competences to Vojvodina. According to sections 65 and 66 of the Law on Establishing the Competences of the autonomous Province of Vojvodina, AP Vojvodina regulates, coordinates and controls employment policy on its territory as a delegated competence. Still the National Employment Service plays major role in the realization with that the coordination of decentralised departments is organized over a regional institution (Pokrajinska služba za zapošljavanje), which also initiates further programs.

As conclusion of this paper I could summaries the following theses:

- Serbia has experienced high losses (professional, moral and material) of labour in the process of transition.

- Experiencing regional differences the Serbian / Vojvodian labour faces new challenges and conditions of success.

- Regional self-organization as a manifestation opportunity of labour does not function in Serbia, even though it has been proven at national economy level that most of the problems could not be solved from the centre. It has also been proven that although tasks and recommendations could be delegated, but their realisation is impossible because of the centralization of financial sources.

- Concerning development of labour there is no approaching, harmonization of interests or communication between business and administrative subjects.

- The political elite is calling attention to the problems only by compiling several strategic documents and generalizing the problems (adult education strategy, employment strategy, migration strategy, strategy on preventing discrimination etc.). The putting into practice of strategies listed in the documents have still not been realized, and in my opinion it will neither be realizable in the long run by the central authorities.

- Due to the pressure of central authority structures regional-local inability to action has prevailed the country.

- In the inability vacuum caused by centralization, individuals (employees, unemployed) try to adjust to market requirements with ad hoc decisions. Conscious EU and real market economy principles reformulate market requirements, while economic subjects are forced to adjust to them.

The competent, competitive human resources in the region (as part of the national economic) could concentrate on economic development, competitiveness, investment attraction, productivity, economic growth, efficiency, acceleration of transition and reform processes, as well as the final (desired) objective of 
constructing EU system of values, realizing EU ambitions - only by decentralized, legitimate, regional institutional, financial and conditions for enforcing interests. In human capital development the emphasis has to be on economic rationality, irrespective of the current development policy beliefs of institutions, revealed in conversations between sectors. 


\section{BEVEZETŐ}

A szerb társadalomban - a politikai problémák, az elhúzódó gazdasági szerkezetváltás, magánosítás következtében - az emberi erőforrás jelentős mértékben sérült, gazdasági, szellemi, morális súlyvesztést élt meg. A munkanélküliség - a makrogazdasági problémák közül elsőként sújtja a szerb társadalmat, és a rendszer „általános cselekvésképtelenségi vákuumában” beárnyékolja, és hátráltatja a szerb gazdaság versenyképességét, sikerességét. A regionálisgazdasági összehasonlító elemzések sürgető intézkedések foganatosítására hívják fel a figyelmet, a folyamatos gazdasági hanyatlás megelőzése érdekében.

A tanulmány a szerb szakirodalmat dolgozza fel, tehát szekunder adatelemzési módszerrel taglalja a gazdasági környezetet, átmeneti időszak sajátosságait, munkanélküliséget, munkaerőpiacot, munkaerő mobilitást, regionális egyenlőtlenségeket. Cél a munkanélküliség nemzetgazdasági és regionális dimenzióinak bemutatása, illetve a regionális foglalkoztathatóság lehetőségeinek feltárása.

Általános feltételezésből kiindulva - miszerint a foglalkoztatáspolitika regionális intézményrendszere müködésképtelen és nem hatékony, valamint a gazdasági és közigazgatási szubjektumok között a probléma megoldását illetően érdemleges dialógus nem indul - további hipotéziseket sorolok fel:

1. A gazdasági térszerkezet alakulását (tranzíció, Schengen, EU) nem követik a foglalkoztatáspolitika proaktív változásai.

2. A régió humántőke fejlesztésében szerepet játszó intézmények között nincs kommunikáció, intézményesült kooperáció.

3. Az egyének (munkavállalók, munkanélküliek) ad hoc. döntésekkel próbálnak meg alkalmazkodni a piac elvárásaihoz.

4. A piac elvárásait tudatos EU - s és valós piacgazdasági elvek formálják át, amihez a gazdasági szubjektumok alkalmazkodni kényszerülnek.

5. A központi hatalmi szervek intézményi legitimitását semmilyen áron és téren nem hajlandóak feláldozni, még a gazdasági racionalitás elveit is hanyagolják, ha azok épp az intézményi (hatásköri, forrásszabályozási) decentralizáció érvei mellett szólnak. 


\section{A MUNKAERŐ MINT PIACGAZDASÁGI TÉNYEZŐ A SZERB TÁRSADALOMBAN}

A piac (így a munkaerőpiac) létezése képezi azt a természetes rendszerszerü környezetet, amely a gazdasági hatékonyság magasabb szintjét garantálja.

A piacgazdaság kiépítésével, minden volt szocialista országban természetszerü jelenségként csökkent a foglalkoztatottak száma. A gazdasági racionalitást, tőkefelhalmozást, termelékenységet és nemzeti/nemzetközi versenyképességet mellőző társadalom-gazdasági rend megszünésével irracionális munkahelyek szüntek meg. A piac hatékonyan szankcionálja a rejtett munkanélküliség jelenségét, a profitszerzés szolgálatába állítva azt. Radić megfogalmazásában a piacgazdaságra történő áttérés fájdalmas, nagy tranzíciós költségeket idéz elö, és az elszegényedett lakosság lemondásait követeli meg (Radić, 2005a, Nagy, 2007). Generációk kényszerülnek egy új, racionálisabb, ugyanakkor az önös érdekek és lehetőségek szempontjából gyakran igazságtalan rendszerhez alkalmazkodni (Radić, 2005a).

A szerb társadalom napról napra éli meg a munkanélküliségtől való félelmet, ugyanis a gyors elhelyezkedés esélyei kicsik, a munkanélküliség átlagos állapota viszont gyakran igen hosszú az átmeneti (válság-sújtott) társadalmakban (Šećibović, 2005). A hatékonyan müködő munkaerő-piac, valamint a gyors gazdasági növekedés és fejlődés érdekében az állam szerepet kényszerül váltani, teret biztosítva a piac általános törvényszerüségeinek (Radić, 2005a, Arandarenko-Ognjenović, 2008). A munkaerö-piac ugyan olyan piac, mint bármely más piac, ahol eladó és vásárló találkozik egymással. A munkaadók vevők, az eladók pedig a munkások. Mindkét fél érdeke a sikeres piaci tranzakció, azaz a jövedelemszerzés (személyjövedelem, illetve a profit). Ugyanakkor a nem teljes konkurencia tökéletlen piacot feltételez, bilaterális - a szakszervezetekbe tömörülő munkások, és a munkaadók érdekképviseleteinek monopóliumaival. A piacon kialakult adott helyzet határozza meg a felek tárgyalási korlátait/lehetőségeit. Az állam bontja meg elsőként a teljes piaci szabadságot, a minimális személyi jövedelemre vonatkozó elöŕrásaival (Radić, 2005a).

A piac müködési zavaraival és a társadalom-gazdasági szerkezetváltás bizonytalanságaival a munkanélküliség mind nagyobb méreteket ölt.

\section{A TRANZICIÓ JELENTŐSÉGE A MUNKANÉLKÜLISÉG SZEMPONTJÁBÓL}

A munkanélküliség egy ország gazdasági és társadalmi állapotának szintetikus indikátora. Az átmeneti társadalmak fö prioritása a foglalkoztatás serkentése, amely esetében Božić két 
feladatot nevez meg: a gazdasági fejlődés felgyorsítását, illetve a foglalkoztatáspolitika rendszerreformjainak véghezvitelét (Božić, 2005). A Balkán tranzíciós országai elsőként a felszínre jutó termeléscsökkenést tapasztalják meg a '90-es évek elejétől. A nemzeti jövedelem per capita automatikusan átrendezte ezen országok rangsorát. ${ }^{7}$

Kísérőjelenségként megjelenik a feltörekvő munkanélküliség. ${ }^{8}$ A '90-es években folyamatosan növekszik a munkanélküliség Szerbiában (Dél-Kelet Európában az egyik legmagasabb), már 2003-ban a 30\%-ot is eléri (Stojić, Atanasov, 2004). A gazdasági szerkezetváltás és magánosítás következményeként (a Nemzetközi Munkaügyi Szervezet módszertanára és adataira alapozva) 2001. és 2006. között megduplázódott, 11\%-ról 21,6\%ra növekedett a munkanélküliség (Arandarenko-Ognjenović, 2008).

Sokić - Artur Okun matematikai modelljére hívja fel a figyelmet: a munkanélküliség természetes munkanélküliség feletti $1 \%$ növekedése a GDP 2,5\%-os csökkenését idézi elő (Sokić, 2008). A Kelet-közép Európai országok szerkezetváltása, a magánosítás folyamata következtében a munkahelyek megtartása válik éppen lehetetlenné, ezzel együtt pedig a gazdasági és termelésnövekedés. Annak ellenére, hogy Szerbia az átmeneti időszak során folyamatos és erősödő gazdasági növekedést valósított meg (5-7\%), a munkanélküliség mégsem csökkent és a szerkezeti problémák és a gazdaságpolitika egyik legnagyobb problémája maradt (Arandarenko-Ognjenović, 2008). A gazdasági válsághelyzet, háború, a piac hiányosságai nehézkes gazdálkodási feltételeket eredményeztek, vállalatok csődbe jutottak, emberek utcára kerültek (Nagy, 2007).

A munkaerőpiac igen specifikusan alakult az elmúlt húsz évben Szerbiában. A munkanélküliség állandó jelenség volt már a jogelőd Jugoszláviában is, amiről tanúskodnak a '89-es adatok, amikor is a munkanélküliségi ráta 17,9\% volt. Marjanović 2002-ben 40\%ra teszi a munkanélküliségi rátát (valós és rejtett munkanélküliség). 1988-tól 2001-ig a foglalkoztatottság Jugoszláviában folyamatosan esik, a munaknélküliség pedig folyamatosan növekszik. Szerbia esetében (a környező országoktól lemaradva) a késleltetett tranzíció folyamatainak eredményeként 2000 után ölt órási méreteket a munkanélküliség

\footnotetext{
7 2004-ben Szerbia a tíz tranzíciós ország közül (Görögország, Szlovénia, Horvátország, Törökország, Románia, Bulgária, Macedónia, Albánia, Bosznia és Hercegovina, Szerbia és Montenegró) a 9. helyet foglalta el Albániát követően az 1400 USD nemzeti jövedelem per capita összehasonlító statisztikák szerint (Božić, 2005).

${ }^{8}$ Bosznia és Hercegovina, Macedónia és Szerbia és Montenegró esetében szem előtt kell tartani a fiktív foglalkoztatottság problémáját is. A társadalmi tulajdonban lévő vállalatok kis kapacitással dolgoznak, veszteségesen, a munkások csak statisztikai adatok formájában léteznek. Szerbiában a számuk a tranzíciós időszak vizsgált szakaszában 300-500 000 (Božić, 2005).
} 
(Božić, 2005). A jugoszláv feketézők számát 2002-ben fél millióra becsüli Marjanović (Marjano vić, 2002).

Božić megfogalmazásában a foglalkoztatás és a munkanélküliség (a jelenség gazdasági és szociális következményeivel együtt) a „tranzíció folyamatának, dinamikájának, minőségének mutatója”. A Balkánon ezek a folyamatok igen hosszúra nyúlnak, magas szintű munkanélküliséggel, amely a lakosság életfeltételei mellett a jövő generációira is nagy nyomást gyakorolnak, ugyanis az átmeneti időszak folyamata teljes körü értékrendszer-váltást követel meg. A munkanélküliség nagyobb, következményei súlyosabbak azokban az országokban, ahol a tranzíció folyamata lassú (Božić, 2005). Ehhez kapcsolódóan Radić Szerbia esetében két átmeneti időszakot különböztet meg, amely a munkaerőpiac létrejötte/létezése szempontjából, de a átmeneti időszakok sikeressége szempontjából is igen meghatározó (Radić, 2005a):

- Első fázis (1.) a ’90-es éveket jellemző mély politikai és gazdasági válság, nemzetközi szankciók, nemzetközi társadalmi kirekesztettség, társadalmi tulajdonviszonyok dominanciája, lassított gazdasági reformok, nehézkes szerkezeti átalakulás, a szürkegazdaság hatalmas részaránya, alacsony szintủ beruházások. Ebben az időszak an munkaerőpiac nem létezik Szerbiában, szimbolikus foglalkoztatás-ügyi intézményi háló létezik, a rejtett munkanélküliség magas. A munkanélküliségtől való félelem mellett a szerb társadalom megismerkedik az infláció és a szegénység fogalmával/jelenségével. Teljes az állami dominancia jelenléte (Pl.: munkajogi törvénykezés, szakszervezeti tárgyalások, stb.), a többi partner megaláztató marginalizálása mellett, hierarchikus kollektív tárgyalásokkal. Állami rendeletek értelmében a vállalatok a szociális nyugalom megőrzése céljából a Kormánynak tettek „felbecsülhetetlen” szívességet. A 2000-res évet megelőző időszakba a politikai rezsim rendelkezett a munkások helyzetét szabályozó szabályzókról, amely egyenes ellentétben állt a piac általános működési elveivel (Arandarenko-Ognjenović, 2008). A legnagyobb maradandó károkat a munkaerőpiac mai szerkezetében éppen ez az időszak hagyta maga mögött. A folyamatosan növekvő rejtett munkanélküliség egyik pillanatról a másikra a munkanélküliek tömegét hozta felszínre, a feketegazdaság virágzását, kettős (legális és illegális) foglalkoztatottságot eredményezett. 
- Második fázis (2.): 2000.-től egy gyorsított ütemủ tranzíció indul be Szerbiában, a munkaerőpiac liberalizációjával, a munkajogi előírások újbóli szabályozásával. A munkahely- szociális nyugalom megtartásának kötelezettségét a külföldi befektetőkre ruházta át az állam, illetve a nemzetközi pénzügyi szervezetek. A munka- illetve a befektetésekre vonatkozó jogi keret többé nem blokkolja a munkaerőpiac szabad müködését, gazdasági hatékonyságot, a munkaadók szabad döntéshozatalát (Radić, 2005a). Más szerzők megkésett tranzícióként említik az utóbbi időszakot. Szerbia a keleti blokk többi országához mérten tíz év lemaradással kezdi meg a piac intézményrendszerének felállítását. Egyik legnagyobb mulasztás a humánerőforrás fejlődésének, a humántőkébe történő befektetések alakulásának intézményi szintű követése (Domazet - Zubović, 2009).

A még be nem fejezett átmeneti időszak (remélhetőleg) végleges harmadik (3.) fázisát a következőképpen jellemzem:

A reformok megkezdését követően a foglalkoztatás törvényes kereteinek módosításai jellemzik a szerb törvénykezést, amelyet egyrészt a közvállalatokban, állami szektorban dolgozók bérének fokozatos emelkedése követett. A szerb munkaerő piaci problémák újbóli fokozódása a magánosítás végső fázisának következményeként kerül (majd) folyamatosan felszínre. Így a reformok más hangvételü eszköztárára van szükség, amely az emberi - és annak müködéséhez szükséges technikai kapacitások fejlesztésében kap szerepet (pl. oktatási reformok a felnőttképzés szabályozásával). Egyre kifejezettebb társadalmi polarizáció veszi kezdetét. A magántulajdon tőkefelhalmozást, ezzel együtt pedig a társadalom rétegeződését eredményezi. Átmenetként továbbra is megmarad az állami szektor „szociális bástyája”, kiegyensúlyozott fizetésekkel (a biztos szavazóbázis bizalma), viszont a kizsákmányolás valós formái is megjelennek, és egyre gyakoribbá válnak (magánszektor).

Szerbia 2009-ben, az átmeneti időszak majdnem teljes lezárását követően kétszámjegyű munkanélküliségi rátát tesz a tranzíció sikerének mérlegére. Kétségtelen, hogy a szerkezeti munkanélküliség jelei a munakerőpiac mind erősebb behatásai miatt egyre kifejezettebbek, ugyanis a munkaerő iránti kereslet és kínálat nem találkozik egymással. Jelen van azonban továbbra is a technológiai munkanélküliség jelensége a szerb gazdaságban, ugyanis a gazdasági szerkezetváltás, a gazdasági hatékonyság felé tett lépések nem tekinthetők befejezettnek. A gazdasági világválság általános nemzetgazdaságra gyakorolt hatása miatt rövidebb - hosszabb ideig érezhető lesz Szerbiában a konjunkturális munkanélküliség is. 
Országunk EU-s ambícióit mérlegelve, a Schengen-t követő időszak feltételezhetjük, hogy a munkaerőmobilitás növekedéséhez, emigrációhoz is hozzá fog járulni. így vegyes, több forrásából fakadó befolyások jellemzik a napjaink munkanélküliségét Szerbiában.

\section{A MEGVÁLTOZOTT GAZDASÁGI KÖRNYEZET ÉS A SZERB MUNKAERŐ}

A „globális kapitalizmus” időszakaként jellemzett jelenkorra jellemző: a transznacionális vállalati dominancia, az állam szerepének (gazdasági erejének/befolyásának) csökkenése, illetve a dereguláció, privatizáció és liberalizáció, amely a szabad piac megteremtésének célját tűzi ki (Marković, 2009, hasonlóan Radić, 2005a).

A tulajdonviszonyi átalakulás folyamatainak befejezésével, várhatóan csökkeni fog az elbocsátások nagysága, intenzitása, ezzel együtt pedig a munkanélküliség. Ehhez azonban hozzá kell járulni a magánszektor jelentősebb beruházási hajlandóságának is, illetve a külföldi tőkebefektetések jelentős mértékű növekedésének. A hazai gazdaság a társadalom fokozatos elszegényedésének következtében a hazai megtakarításból származón potenciális pénzeszközökre nem számíthat (Domazet - Zubović, 2009).

A foglalkoztatás elaszticitásának indikátorát elemzik tanulmányukban Domazet - Zubović. Amennyiben az foglalkoztatás elaszticitásának értéke 1, akkor leegyszerüsítve a GDP 1\%-os növekedését, a foglalkoztatottság 1\%-os (azonos százalékarányú) növekedése követi. Az átlagos nemzeti aggregált foglalkoztatási elaszticitás 0,10 és 0,70 között mozog, azaz lassabban növekszik a foglalkoztatottság, mint a GDP (Choi, 2006. Idézi: Domazet Zubović, 2009). Szerbiában 2002 és 2008 között a foglalkoztatás elaszticitása negatív volt: 0,16 (a mezőgazdaságban -0,02, az iparban - 2,14). Az EU27-ek átlagos foglalkoztatási elaszticitása 0,46\%. A Szerbiára jellemző foglalkoztatási rugalmatlanság a tranzíció következménye (a magánosítás folyamata, vállalati átszervezések). 
1. ábra

A foglalkoztatottak számának alakulása az egyes tulajdonformák esetében Szerbiában, 2004-2007 között.

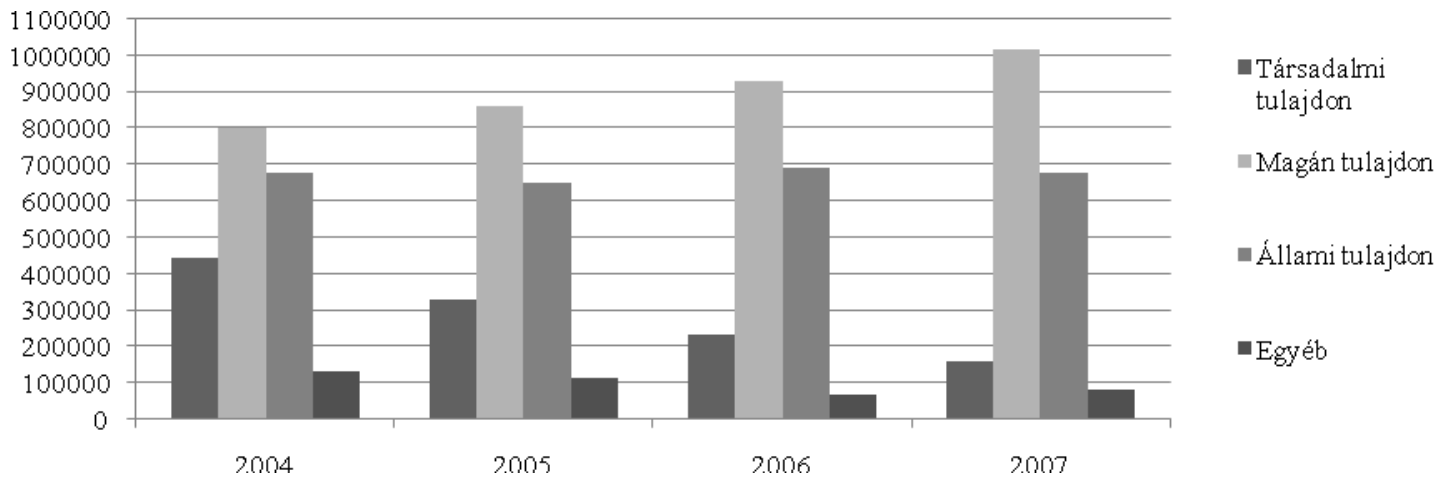

Forrás: Domazet - Zubović, 2009 alapján saját szerkesztés.

2. ábra

A foglalkoztatottak megoszlása a vállalati struktúrán belül 2002-ben és 2007-ben

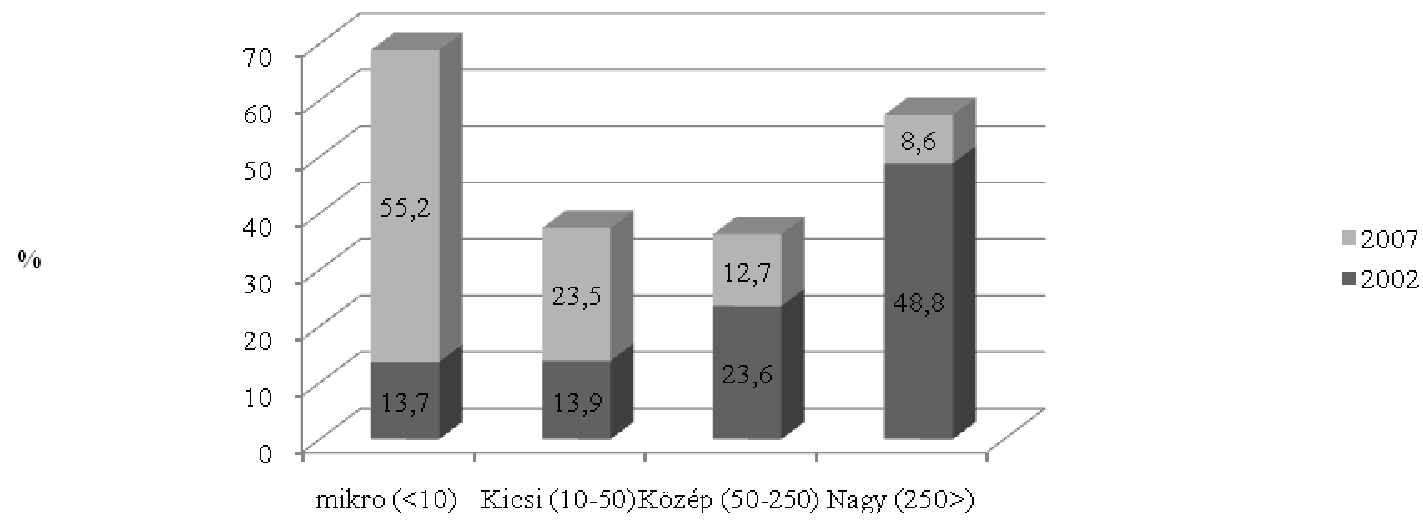

Forrás: Domazet - Zubović, 2009 alapján saját szerkesztés.

Szembetűnő (1. ábra) a magántulajdonban dolgozók számának folyamatos növekedése, illetve a társadalmi tulajdonú gazdasági szubjektumok által foglalkoztatott személyek lassú, ugyanakkor folyamatos csökkenése. Mivel az előző társadalmi-gazdasági formáció nagyvállalati struktúrája nem volt versenyképes, helyüket a mikro vállalatok váltották fel, amelyekben egységenként tíz, illetve annál kevesebb foglalkoztatott dolgozik ${ }^{9}$ (2. ábra). Az újonnan alapított gazdasági szubjektumok gazdaságunk három (legperspektivikusabb)

\footnotetext{
${ }^{9}$ Szerbiában, a 2006-os évben újonnan alapított cégek 99,3\%-a kicsi illetve mikro-vállalkozás (ArandarenkoOgnjenović, 2008).
} 
ágazatában jelennek meg: kereskedelem, építőipar, ingatlanok. A Cégbejegyzési Ügynökség 2007-es adatai alapján a cégek között - jogi formájukat tekintve - legtöbb a vállalkozó (preduzetnička radnja) és a Kft (doo). A Kft részaránya 27,5\%. Az össz szerbiai jogi személy mintegy 4\%-a számolhat be külföldi tőkeeredetről (Arandarenko-Ognjenović, 2008).

A foglalkoztatás flexibilis formái alapjában véve nincsenek jelen a szerb munkaerőpiacon (részmunkaidő, önfoglalkoztatás, stb.) (Stojić, Atanasov, 2004). Elsősorban az alacsonyan képzett munkaerő körében jelentkeznek ezek a foglalkoztatási formák. A jegyzett foglalkoztatottak mindössze $13 \%$-a végez időközönkénti, szezonjellegű, meghatározott idős munkát (Arandarenko-Ognjenović, 2008).

A gazdasági környezet változása - a tranzíció kezdetén megfogalmazott elvárásokhoz viszonyítva, sajnos több dimenzióban sem teljesült. A külföldi tőkebefektetések és a magánosítás sikerébe vetett remény alaptalannak bizonyult, alacsony a külföldi vállalatok, nagyvállalatok részaránya. Problémát jelent továbbá a tény, hogy a mikrovállalatok kis fejlődési potenciállal rendelkeznek, illetve, hogy a magánszektor nem tudja megfelelő gyorsasággal és kapacitással felszívni a társadalmi szektorban felszámolt munkahelyekről kikerülő munkaerőt. A szerkezeti munkanélküliség jelenségével kell megbirkózni a szerb társadalomnak.

\section{A HUMÁNTŐKE INNOVATIV SZEREPE}

A technológiai fejlődés eredményeképp az ember gépekkel válik helyettesíthetővé, és a nemzetközi tőkevándorlás eredményeként a tőke-ki - és betelepülésének jelenségét figyelhetjük meg a termelési költségek és a gazdasági racionalitás elveinek érvényesülésével. Az információs technológia új korszakot nyit meg a humántőke fejlődésében, ugyanis az ember döntéshozatali, ellenőrzési szerepe válik prioritássá. Major „a termelö emberek társadalmából” az „alkotó ember társadalmába” történő átváltozással jellemzi ezt az időszakot (Major, 1991. Idézi: Marković, 2009).

Az átmeneti időszakkal a humán erőforrás átváltozásának is meg kell történnie, előrehaladást kell mutatnia. Az átmeneti országok a munkaerő komoly szerkezeti változásaival, átszervezével szembesülnek (Šuljmanac-Šećerov - Durman, 2006), ahol a munkanélküliség mindinkább a munkaerő nem megfelelő kínálatának (szakképzettség, mobilitás, flexibilitás hiánya, stb.) az eredménye (Božić, 2005).

A tudás strukturális erő, amely képes az embereket, rendszereket megváltoztatni, a humánerőforrás minőségét javítani, és képes a munkaerőpiacot modernizálni, 
érdekegyeztetési összhangot teremteni vagy legalább is keresni a foglalkoztatottak és munkaadók között. A humánerőforrás képesítésével (képessé tételével) megvalósítható a társadalmi és gazdasági fejlődés, annak minősége, mértéke (Zjalić, 2009). A foglalkoztathatóság és elhelyezkedés (új) lehetőségei a piac szükségleteinek függvényében alakulnak. A piaci szükségleteket a tőketulajdonosok - munkáltatók formálják, igényeikkel, elvárásaikkal, gazdasági racionalitásukkal (Pejić, 2005, Szlávity, 2008, Takács, 2008). A foglalkoztatottak munkájuk megtartása érdekében folyamatos tudás-megújításra kényszerülnek, élethossziglani tanulás (Life Long Learning - LLL) által biztosítva „munkahelyük állandósága” helyett a mindenkori állandó szakmai felkészültséget. „A társadalom minden egyes tagja egy állandó tanulási folyamat részesévé válik: megalapozva, egy tanuló társadalom létrejöttét" (Németh, 2005).

Mivel a tudás meghatározó gazdasági erővé válik, nélkülözhetetlen az emberi erőforrás folyamatos fejlesztése (Zjalić, 2009). Az emberi tőkébe történő befektetés a legegyszerübb gazdasági logikát követő gazdasági cselekmény, mégis kevés ország tulajdonít kellő figyelmet, stratégiai megközelítést a beruházás ezen válfajára (Šuljmanac-Šééerov Durman, 2006, Sokić, 2008, Arandarenko-Ognjenović, 2008). Sok esetben a termelési tényezők közül a tőkét tartották deficitárus (a gazdasági fejlődést hátráltató) tényezőként, sajnos azonban azt tapasztalhatjuk, hogy az emberi erőforrás is sokszor képez „szük keresztmetszetet” egy gazdaságban (Zjalić, 2009). A megfelelő szaktudás, rátermettség, inovatív készség, jó ötletek hiányában nehezen képzelhető el bárminemü fejlődés. A tudás valójában az emberi tőke ügyességében, találékonyságában, képzettségében, innovatív képességében fejezhető ki, amely képes az egyéb tőkeformák optimális és legracionálisabb felhasználására (Sokić, 2008). Az emberi tőke profitszerzést szolgál (Sokić, 2008), közvetlenül képes értéktöbblet megvalósítására (Zjalić, 2009). Ugyanakkor ez az információ és tudás-tőke gyorsan elavul, használhatatlanná válik, amely megújításának anyagi vonzata igen jelentős (Radić, 2005a). Zjalić a tudás megfelelő irányítását az intellektuális tőkébe történő befektetéssel egyenlíti ki, amely szervezeti szinten hoz jobb eredményeket (Zjalić, 2009). Új szakmák megjelenése, a technológiai fejlődés következtében pedig régi szakmák eltűnésére kell számítani, amely során az oktatási rendszernek kell megfelelő, flexibilis nómenklatúrát biztosítania (Pejić, 2005, Šuljmanac-Šéererov - Durman, 2006, Takács, 2008, Gábrity Molnár, 2009a, 2009b, Marković, 2009, Zjalić, 2009).

Radić hat technológiai változást, nagyobb inovációt említ egy munkás életében, amely állanó alkalmazkodást és felkészültséget, továbbképzést, új tudás megszerzését követeli meg. Az új technológiák alkalmazásának késésével kiszorulnak a piacról a vállalatok. Cél 
tehát, szociális költségek árán is biztosítani a munkaerő állandó felkészültségét, a humántőke folyamatos fejleszthetőségét, ami a hosszútávú versenyképesség feltétele is egyben (Radić, 2005b).

Gábrity Molnár a fejlett országok gyakorlatára hívja fel a figyelmet, ahol a munkaképes lakosság képzettségi szintje folyamatosan emelkedik, a munkások képességeik szerint történő elhelyezésére, átirányítására, átképzésére pedig külön hangsúlyt fektetnek (Gabrić Molnar, 2000). Ahhoz, hogy a humántőkébe történő befektetések ne legyenek „,befektetési kudarcok”, elhibázott beruházások”, fó irányelvként a gazdaság és a munkaerőpiac szükségleteit kell szem előtt tartani. Csak ebben az esetben lehet „az emberi tőkébe történö beruházás a XXI. században a siker kulcsa” (DfEE, 2000. Idézi: Zjalić, 2009).

A globalizáció, globális kapitalizmus, tudáson alapuló kapitalizmus (knowledge capitalism) megjelenésével, a társadalmi gazdasági formáció szinte teljes egészében a pénz-és fizikai tőke helyett az intellektuálisra helyezi a hangsúlyt (Marković, 2009), kiemelve az emberi erőforrás jelentőségét (Zjalić, 2009), amelynek valós piaci körülmények között mutatkozik meg versenyképessége, minőségi és mennyiségi korlátossága, egyéb termelési eszközökkel történő helyettesíthetősége. Az emberi erőforrás megoldással tud szolgálni a világgazdasági recesszióra, a globalizáció kihívásaira, ezzel együtt a társadalom-gazdasági fejlődés új törvényszerüségeire (Sokić, 2008).

A nemzetközi, foglalkoztatás-ügyet érintő problémákkal Szerbia EU-s integrációt megelőző és követő időszakokban is szembesülni fog. A szabad munkaerő-mozgás kiélezi a versenyt, mind inkább kiefejzésre jut a humántőke minősége. Az országnak számolni kell munkaerőveszteségekkel is, ugyanis munkahelyek hiányában a munkaerő elvándorol. Radić érvelését szem előtt tartva: a munkanélküliség ára magas „kérdés milyen mértékig elégíthető ez ki szociális juttatások formájában, és hol kezdődik a fiatal emigránsok miatti potenciális termék-kiesés pótlása?” (Radić, 2005a). A munkanélküliség - amelyet Sokić a gazdaságban a munka kihasználatlanságaként fogalmaz meg - megfékezhető a munakerőpiac inovatív eszköztárával (Sokić, 2008).

Európai Uniós példák is azt mutatják, hogy a munkanélküliség problémájának megoldására univerzális recept nem létezik. A tagállamoknak törekedniük kell arra, hogy megteremtsék, és folyamatában megtartsák a munkaerőpiac flexibilitását, ezzel együtt polgáraik számára a jobb munkakörülményeket, életfeltételeket. Európa a munkaerő mobilitásra helyezi a hangsúlyt. Radić ezzel kapcsolatban kiemeli a munkaerő széleskörü jogainak szabad gyakorlását, mint a foglalkoztatás szociális dimenziójának elemét (Radić, 2005b). Stojić EU 
- s foglalkoztatáspolitikai célpontok között említi még: a munkaszervezés flexibilitásának megteremtését (munkaidő, mobilitás, stb.) (Stojić, Atanasov, 2004).

A foglalkoztatás a „társadalmi integráció legjobb formája, amelyet Európai a XXI. század prioritásai közé sorol”. A szegénység és szociális problémákkal szembeni legerősebb védelem a foglalkoztatás (Stojić, Atanasov, 2004).

Gazdasági előnyként említhető a munkaerő szabad mozgása, illetve az egységes piac elvének érvényesülése is. Az Európai Unió foglalkoztatáspolitikájának célja a gazdasági és szociális fejlődést, valamint az életminőség fejlődését biztosító magas foglalkoztatottság, és alacsony munkanélküliség megteremtése.

\section{A MUNKAERŐ MOBILITÁS IRÁNYAI SZERBIÁBAN}

A munkanélküliségtől való menekvés eredményeként az egyén sok esetben kivándorlás mellett dönt. A befogadó országok azonban gyakran csak a magasan képzett (esetleges hiányszakmát képviselő) munkaerővel szemben nyitottak. Az egzisztenciális feltételek biztosításának kényszerében az „itthon ragadt” munkaerő a feketegazdaságban keres jövedelemszerzési lehetőségeket.

A munkaerő mobilitás külföldi irányultságával kapcsolatban Zjalić egyre erősödő migrációs folyamatokat említ (Zjalić, 2009). Az Európai országok fejlettségüknél és a magas béreknél fogva, vonzó célpontok a kivándorlók számára, ugyanis a tagjelölt, vagy potenciális tagjelölt országokra jellemző a magas munkanélküliség és alacsony bérek (Stojić, Atanasov, 2004). A kivándorlás azonban erősebb, tradicionálisabb szálakon mozog Szerbiában.

A jugoszlávok tömeges külföldi munkavállalása több évtizeden át szociális, gazdasági, erkölcsi, politikai és kulturális okokkal magyarázható (Gábrity Molnár, 2006b). Az egykori jugoszláv szocialista államapparátus által „ideiglenesen külföldön munkát vállaló (temporary labour migrants Grečić, 2001)"”10 emigránsok száma 1971-től, a népszámlálási adatokat figyelembe véve folyamatosan növekedett (Gredelj, 2006, Gábrity Molnár, 2006b). Becslések szerint 2,5 millió (további becslések szerint pedig négy millió) ${ }^{11}$ szerb, illetve szerb származású ember él Szerbián kívül (Gredelj, 2006).

Az emberek migrációról kezdenek gondolkodni, amikor tarthatatlnnak érzik a stabilitás vesztését - önmagukban, környezetükben, a társadalmi intézményi rendben (Mežnarić, S., 2003). Mihailović az átmeneti időszakot emeli ki, amelyre jellemző a gerontokrácia,

\footnotetext{
${ }^{10}$ Gredelj jelentős „kiviteli cikként” jellemzi őket 1,2 milliárd DM átlagos évi devizatranszferrel (Gredelj, 2006).

${ }^{11}$ Strategija za upravljanje migracijama = Službeni Glasnik RS. Br. 59/2009.
} 
önmegsemmisítő közösségi szellem, elvadulás, biológiai fennmaradási harc. A '90-es évek, az ezredforduló, és a lehetséges jövő „áldozatainak” nevezi ezeket a generációkat (Mihailović, S., 2004).

Mihailović tanulmányában minden második szerbiai fiatal menne, Európába, „és a fejlett világba, önállóan, Szerbia nélkül’! A többiek pedig esetleg Szerbiával Európába, vagy inkább Szerbiával egy időgépbe, vissza az „ünnepelt múltba”. 12 Általános megállapításként: két évtizede a fiatalság csak arra vár, hogy „diplomázzon és emigráljon” (Mihailović, 2004).

Az ,agyelvándorlás-agyelszívás” '90-es években megkezdődött folyamata a napjainkig folytatódik (Arandarenko-Ognjenović, 2008). A munkanélküliség problémája, alacsony bérek, gazdasági és politikai krízis kilátástalansága miatt az elmúl húsz év a lakosság intenzív emigrációjával is jellemezhető, elsősorban a jóléti államok felé, így a Balkán, vele együtt Szerbia is „a legjobbak nélkül“ maradt (Božić, 2005), szegényes intellektuális tőkével szembesülve. Mihailović a fejletlen és tranzíciós országok kifejezetten erős jelenségeként számol be a „brain drain“ jelenségről, amelyet a Balkánon már „brain flightnek" neveznek (Mihailović, S., 2004). A '90-es évektől Jugoszláviát mintegy 30000 magasan képzett szakember ${ }^{13}$ hagyta el (Grečić, 2001). Gredelj a „tudományos és kutatói gárda újratermelésének “14 „az intellektuális tőke szétszóródásának“, Gábrity Molnár a „profilok pótolhatatlanságának“ problémáját említi (Gábrity Molnár, 2008a).

A cél-országok közé a '90-es évek változásait követően Magyarország is bekerült. ${ }^{15}$ Erről számol be egy - a Magyarország felé irányuló szerb népességmozgásról szóló kutatás, amely a 2001 és 2008 közötti, Schengen előtti időszak folyamatos kivándorlására hívja fel a

\footnotetext{
121999 és 2003 között Horvátországban végzett különböző empirikus kutatások eredményei a fiatalok cca. 40\%-a menne, ha lehetősége volna, akár örökre is (Mihailović, 2004).

${ }^{13}$ highly qualified personnel, highly skilled workers, qualified personell, human resources in science and technology, sciences and engineers, IT workers, vagy egyszerüen „brain“ (Grečić, 2001).

14 1979-1994 között Szerbia kutatóintézeteiből 1256 (a tudományos elit 10\%-a) szakember távozott. Ezen emigránsok több mint fele 40 év alatti, többnyire természettudományokkal foglalkozó (fizika, kémia, matematika, egészségügy és elektronika területei) kutató volt. Az oktatásukba befektetett mintegy három milliárd dollár direkt veszteséget jelent Szerbia számára, az indirekt következményeket nem is számolva (Gredelj, 2006.).

${ }^{15}$ Az áramlás iránya a '80-as évek végéig a nyugat- és közép-európai országok voltak: NSZK, Ausztria és Franciaország. 92\%-uk Európa, míg 7,2\%-uk Európán kívül, a tengerentúlra távozott (Gábrity Molnár, 2006a, 2008a). Németország a legattraktívabb ország a jugoszláv migránsok, munkások, menekültek, azilok és politikai emigránsok számára. Pavlica 1990-ben 600.000 jugoszlávról számol be, amely a hazai emigránsok 25\%-a, az 1991-es Népszámlálás adatai szerint. Németország után Ausztria (22,5\%), Svájc (14,1\%), Franciaország (7,7\%), Svédország (3,5\%), USA (6,3\%), Kanada (2,2\%), Ausztrália (1,9\%) területén éltek a jugoszláv emigránsok. 1990-et követően Németország tömeges menekültáradatot jegyez: 1994-ig 316243 főt, majd 1995-1999 között pedig újabb 156645 menedékjoggal rendelkező személyt (Pavlica, 2005). Megjegyzés: Öt év alatt megközelítőleg annyi jugoszláv menekült érkezett Németországba, amennyi menekült 1988 és 1999 között összesen Magyarországra érkezett: Európából, a világból.
} 
figyelmet, amelyben Budapest és Pest megye Magyarország általános dinamikus bevándorlási központja, míg a Vajdaság a kivándorlás központi térsége (Kincses - Takács, 2010).

Az emigrációból származó veszteségek között Gábrity Molnár emberi, anyagi, illetve demográfiai jellegüeket említ, amely következményeképp a „régió erötlensége, fejlődési lehetőségeinek hiánya” jelenik meg (Gábrity Molnár, 2008a). A szakemberhiány számos további probléma forrása: lassuló gazdasági fejlődés, munkatermelékenység csökkenés, innováció hiánya, technológiai elmaradás, versenyképesség fokozatos vesztése, stb. A fiatal férfierő „conscious objectors CO”, „dezertőrök” hiánya demográfiai veszteség, amellyel gazdasági is párosul (potenciális profitkiesés, anyagi, erkölcsi és biológiai reprodukció), mindent összevetve civilizációs és irreverzibilis veszteségekként összegezhetők az emigráció eredményei (Gredelj, 2006).

Šuljmanac-Š - Durman kiemelik a munkaerő mobilitási (földrajzi és professzionális) korlátait, amelyeknek köszönhetően munkahelyek maradnak betöltetlenül (ŠuljmanacŠećerov - Durman, 2006). A belső migráció egyik tipikus formája a faluból-városba irányuló mozgás. Savić a Vajdaság belső migrációs potenciáljára figyelmeztet, Újvidék egyben a városközi migráció fő célpontja is, elsősorban gazdasági okok miatt (Savić, 2008). A migráció harmadik irányaként Šuljmanac-Š - Durman a feketegazdaságot emelik ki ( ̌́uljmanac-Šéérov-Durman, 2006).

A feketegazdaság általi „illegális foglalkoztatás“ a tranzíciós országok foglalkoztatáspolitikájával szembeni, talán egyik legnagyobb kihívás. A gazdaság és államirányítás müködőképességi zavara olyan helyzetet teremt, amelyben a sok munkát kereső, munkahelyek hiányában, alacsonyabb fizetések mellett (szociális és egyéb jogoktól megfosztva), a munkaadó kizsákmányoló - profithajhászó üzletelésének áldozata lesz.

A szociális nyugalom megőrzése érdekében az állam szemet huny a közjövedelem-kiesés felett, engedélyezi a bolhapiaci csencselést (buvljaci), üzérkedést, mondván „az embereknek meg kell élni valamiből a nehéz idők során” (Božić, 2005). Ezekben a nehéz időkben, 2000ben Szerbiában a munkanélküliek 1/5-e, a közszférában foglalkoztatottak 1 /4-e kereste megélhetési lehetőségeit a szürkegazdaságban (Stojić, Atanasov, 2004). A Világbank 2006os jelentése szerint Szerbiában az teljesfoglalkoztatottak 43\%-át a nemhivatalos szektor foglalkoztatja, illetve a munkaadóknál a munkások 26,7\%-a illegális munkavállaló (Arandarenko-Ognjenović, 2008).

A külföldi tőkebefektetések, munkahelyteremtő programok, gyors gazdasági fejlődés, gazdasági szerkezetváltás hatékonysága tudják csak a problémát enyhíteni. A befektetők 
cserébe stabil politika helyzetet, megfelelő befektetési klímát, működőképes (átjárható, átlátható) jogrendszert várnak el. A vállalkozói szándékot-cégalapítást befolyásolják a különböző engedélyek, licencek, hitelkérelmezési korlátok, korrupció, adminisztratív és bírósági eljárások. Átlagosan 18 nap szükséges Szerbiában egy cég megalapításához (Arandarenko-Ognjenović, 2008). Sokban hozzájárul a gazdasági közösség bizalmatlanságához a politika rendszer instabilitása, egyenlőtlen versenyhelyzetek, infunkcionális piaci viszonyok, munkajogi összehangolatlanság, nem következetes (és kötelességtudó) fiskális politika (Božić, 2005).

A 2010-es évre kialakult helyzet általános összegzéseként fontosnak tartom kiemelni:

- Annak ellenére, hogy Szerbiában a munkatörvények átfogó reformja megtörtént, a foglalkoztatás törvényes mederbe történő terelése nem mondható sikeresnek. A magas járulék- és adóterhek miatt továbbra is kevesen képviselik a legális foglalkoztatás bármelyik törvényes formáját, és a munkaigényes tevékenységekbe is kevés befektetés történik Továbbra is sok a feketézés, illegális foglalkoztatás, minimálbérrel történő alkalmazás, de egyértelmü, hogy a vállalkozók körében jelen van más jellegű adócsalás, járulékmegkerülés is. Az állam a cselekvésképtelenségi kényszerhelyzetében joghézagossággal (mégis törvényes keretek között) old meg feketegazdasági manipulációkat, és akadályoz meg további szociális problémák felszínre kerülését.

- Az állam és rendszerbeli hiányosságok, munkanélküliségi problémák kulminálódása következtében az emigráció veszélye továbbra is fokozottan fennáll.

- EU-s távlatokban gondolkodva, újra a magasan szakképzett, magas professzionális és területi mobilitással rendelkező munkaerő-veszteség forgatókönyve ismétlődhet meg.

- A „virtuális hazatérés” Szerbia esetében müködésképtelennek bizonyult, és utópisztikus, nosztalgikus sóvárgást eredményezett.

- Nemzeti (körültekintő) intézkedésekkel, hálózatépítési (networking) törekvésekkel kell a mai generációk fejlődését biztosítani, elvándorlásukat megakadályozni.

- Ehhez azonban megfelelő alapot csakis a regionális önrendelkezés, regionális felelősségvállalás szolgáltathat, ahol a humántőke gazdasági szerepét a fiskális decentralizációból származó eszközökkel elismerni, honorálni tudják a helyiregionális elit képviselői. 
- A devizatartalékok a szociális biztonság, nyugalom megtartására irányulnak, nem szisztematikus, hálózatos együttműködések formájában működtetett tőkemobilizációt szolgálnak.

\section{ESÉLYEGYENLŐSÉG/ESÉLYEGYENLŐTLENSÉG A MUNKA VILÁGÁBAN}

Az európai foglalkoztatáspolitika értékrendjében, a munkába állás egyenlő feltételei kiemelt helyen szerepelnek (nemi, etnikai, egészségügyi, területi származásbeli szempontokat érvényesítve).

Balon tanulmányában a nemi alapú megkülönböztetést emeli ki Szerbia esetében. Szerbiában erről a problémáról 2005-től kezdve beszélünk (Balon, 2007). ${ }^{16}$ A nők Szerbiában:

- képzettebbek a férfiaktól,

- alacsonyabb vezetői pozíciókat töltenek be,

- átlagosan kevesebbet keresnek, összehasonlítva férfi kollégáikkal,

- alacsonyabb a társadalmat érintő kérdésekben meghozott döntésük súlya.

Az EU - 25-ök statisztikáiban az egyetemisták 55\%-a nő, a menedzserek 1/3-a (32\%) nő, de átlagosan 15\%-kal kevesebbet keresnek férfi társaiktól, ugyanakkor többet dolgoznak, és kevesebb a szabadidejük. A foglalkoztatottsági ráta a nők esetében alacsonyabb, 56\%, míg a férfiak esetében $71 \%$. A nők cca. 1/3-a dolgozott fél munkaidővel, míg a férfiak mindössze 7\%-a. (Eurostat, 2006. Idézi: Balon, 2007).

Szerbiai statisztikai adatokat összegezve Balon a következő megállapításokra jut: Szerbiában a parlamenti képviselők (2002, 2004) 11-13\%-a nő, a tartományi parlamenti képviselők (2003-2007) 6,7\%-a, majd 2007-ben 19,7\%-a nő (Božanić, 2007). Az aktív lakosság között a nők 30,4\%-a van vezetői beosztásban Szerbiában (Balon, 2007). A Vajdaság Autonóm Tartomány alapításával müködtetett intézmények irányításában a nők szerepe jelentősebb: a felügyeleti bizottsági tagság/elnöklés: 39/38,5\%, igazgatóbizottsági tagság/elnöklés:26,7/21,4\%, míg a foglalkoztatottak 53\%-a nő ezekben az tartományi intézményekben (Božanić, 2007).

$\mathrm{Az}$ egyetem alapképzéseiben nagyobb arányban vannak jelen a nők (53\%), míg a posztgraduális képzéseken számuk jelentősen leesik (30-33\%). Közép és felsőfokú

\footnotetext{
${ }^{16}$ Republički zavod za statistiku: Žene i muškarci u Srbiji (Balon, 2007).
} 
képesítéssel mégis a nők 58\%-a, míg a férfiak mindössze 46\%-a rendelkezett 2002-ben. A vállalatokra vonatkozó statisztikák is azt mutatják, hogy a munkában álló nők képzettebbek férfi társaiktól (100 : 114 felsőfokú végzettség esetében, 100 : 136 főiskolai végzettséggel rendelkező nők esetében).

A személyi jövedelmek tekintetében nemi alapú diszkriminációra utaló adatokat emel ki Balon: ágazattól függően akár 25\%-kal kevesebb pénzt keresnek férfi társaiktól a szerbiai nők. A felsőoktatási intézményekben részarányuk alacsony, 29\% (egyetemek) - 38\% (föiskolák) (Balon, 2007). A vajdasági felsőoktatási intézmények, egyetemi karok vezetői beosztásaiban a nők részaránya szintén alacsony dékán: 15,4\%, katedra-vezető: 23,5\%, dékán-helyettes: 28,6\% (Božanić, 2007).

A 2006-os szerbiai statisztikai adatokat elemezve láthatjuk, hogy a nők körében magasabb a munkanélküliségi ráta (nők: 25,5\%, férfiak: 18,6\%), ugyanakkor alacsonyabb a foglalkoztatottsági részarányuk férfi társaiktól (nők: 40,6\%, férfiak: 59,2\%). A 25-45 éves korcsoportba tartozó nők körében határozottan magasabb a munkanélküliség, mint a férfiak esetében. A munkanélküliek iskolavégzettségi összetételében alacsonyabb eltéréseket figyelhetünk csak meg, férfiak és nők között (felsőfokú végzettségű nők: 10\%, férfiak: 8\%) (RZZS, 2008). A szerbiai nők inaktivitásának problémájára hívja fel a figyelmet Arandarenko-Ognjenović (nők: 54,5\%, férfiak: 72,7\%) (Arandarenko-Ognjenović, 2008). Szlávity a női dolgozók számára, a családi szerepvállalás mellett megfelelő megoldásnak a rugalmas kisvállalkozások formáját tartja elfogadhatónak (Szlávity, 2008).

Gábrity Molnár megfogalmazásában „az egyenlötlenség problémáját az éj leple alatt nem lehet megoldani, mivel ez öröklött jelenség és széleskörü társadalmi ínségekböl, illetve a társadalmi munkamegosztás mélyebb hiányosságaiból fakad” (Laki et al, 1997). Az igazságos társadalom utópiáját olyan „,hatalmi megosztásban” lehetne megfogalmazni, ahol a bizonyos eljárások és folyamatok (így a foglalkoztatás terén megnyilvánuló egyenlőtlenségek) megvalósításához egyenlő hatalmi szintérre lehet számítani (Marković, 2009).

Etnikai alapú munkarőpiaci egyenlőtlenségek is fellelhetők Szerbiában. Gábrity Molnár a magyarság pozícióvesztésére mutat rá. Az országos, illetve a vajdasági átlagnál is alacsonyabb a magyarok körében az elitfoglalkozások részarány (pl.: közalkalmazottak), a magyarok 1/3-a mezőgazdasági munkás, míg további 1/3-a feldolgozóiparban, építőiparban dolgozik (Gábrity Molnár, 2008b). A leghátrányosabb helyzetủ etnikai csoportot a romák képviselik. A teljes roma populáció 60\%-a munkanélküli. Mindössze 10\%-uk hivatalosan 
foglalkoztatott, elsősorban építőiparban, kommunális szolgáltatásokban, bányászatban, 2\%uk saját biznisszel, azaz (hivatalos) önfoglalkoztatással (RZZS, 2008).

Továbbtanulási szándék és foglalkoztatás területén is erősen megmutatkoznak a származási hely (falu-város) általi egyenlőtlenségek. A rurális térségből származók hátrányos helyzetüek (Gábrity Molnár, 2008b). A fiatal munkavállalókról empirikus kutatások során kiderültek: nem jelentkeznek be a foglalkoztatásügyi hivatalokba, sok közöttük a tartósan munkanélküli, a foglalkoztatottak pedig átlagosan akár évenként is váltanak munkaadót, emigráció gondolata is foglalkoztatja őket, nem rendelkeznek kiforrott nemzetiségi kapcsolatrendszerrel (Gábrity Molnár, 2008c).

A menekültek száma Szerbiában, 2007-ben 303.769 volt. 27,9\%-uk munkanélküli (Opačić, 2007. Idézi: Arandarenko-Nojković, 2007). Célorientált betelepítésük/betelepülésük eredményeképp ma a legfejlettebb régiókban dolgoznak, ugyanakkor a helyzetük instabil, alacsonyabb rendü munkák állnak csak rendelkezésükre. Alacsony az önfoglalkoztatás, magas a feketézés, 37\%-uk nem hivatalosan, bejegyzett cég nélküli önfoglalkoztatott (Arandarenko-Nojković, 2007).

A rokkantakkal szemben tanúsított, elsősorban a munka világában felszínre kerülő diszkrimináció kivédését hivatott szolgálni a 2006-ban elfogadott törvénycsomag, tovább a munkatörvény munkaadók felé irányozott adókedvezményei, illetve a nemzeti foglalkoztatáspolitika által kezdeményezett programok, amelyek eredményeként 2006-ban 200 rokkant, fogyatékkal élő személy kapott munkát. ${ }^{17}$ 2010-ben lépett életbe a rokkantak és különböző hendikeppel élők foglalkoztatására vonatkozó törvény, miszerint a munkáltató minden 50 foglalkoztatott után 1 rokkant személyt is munkaviszonyba kell, hogy állítson. ${ }^{18}$

Esélyt az egyenlőségre, illetve egyenlő hatalmi szinteret jelenthet a nemzetgazdaság szintjén egy regionális intézményi rendszer müködése, amely valós autonómiákkal rendelkezik, és gazdaságát a makrogazdasági (globális, nemzetközi) trendek irányába viszi, ügyelve az esélyegyenlőség - az esetleges faji, nemi, etnikai, stb. megkülönböztetések felszínre kerülésének megakadályozására. A sérülékenyebb társadalmi rétegek/csoportok valós igényeire csak regionális intézményi érdekszervezetek szánhatnak elegendő figyelmet. Néhány sérülékeny társadalmi csoport által generált, láncreakciókat kiváltó probléma valós

\footnotetext{
${ }^{17}$ Zakona o sprečavanju diskriminacije osoba sa invaliditetom = Službeni Glasnik RS. Br. 33/06 és Strategije unapređenja položaja osoba sa invaliditetom u Republici Srbiji http://www.region.vojvodina.gov.rs/images/stories/strategije/Strategija\%20unapredjenja\%20polozaja\%20osob a\%20sa\%20invaliditetom\%20u\%20Republici\%20Srbiji.pdf (Letöltve: 2010.01.31.)

${ }^{18}$ Zakon o profesionalnoj rehabilitaciji i zapošljavanju osoba sa invaliditetom = Službeni Glasnik RS. Br. $36 / 09$
} 
forrása, egyéb kihatásai a központi hatalmak számára nem lesznek érthetőek, mert a problémák nem általánosíthatók (romakérdés, menekültügy, a nők társadalmi szerepe foglalkoztatottsága, stb.).

\section{NEMZETI FOGLALKOZTATÁSÜGYI - MUNKANÉLKÜLISÉGI ÖSSZEFOGLALÓ 2009}

Szerbiában a 2009-es évre vonatkozó, EUROSTAT módszertanára épülő, munkaerő állapotjelentés $^{19}$ alapján a munkaerőpiac szereplőinek sajátosságait a következőkben összegezhetjük: Szerbia összlakossága 7.528.262, ebből a 15 évnél fiatalabbak száma 1.177 .934 (16\%), míg a 15 évnél idősebbek száma 6.350 .328 (84\%). A 15 évnél idősebb lakosság 35,1\%-a foglalkoztatott, 6,5\%-a munkanélküli, míg az érintett szerb populáció 42,8\%-a inaktív. Az inaktív lakosság teljes száma 3.219.048, míg az aktív lakosság száma 3.131.280 (ARS, 2009).

Az aktív lakosság 84\%-a foglalkoztatott, míg 16\%-a munkanélküli. A foglalkoztatottak megoszlása: 1. helyen a foglalkoztatott munkások 1.780 .758 (57\%), 2. helyen az önfoglalkoztatottak 626.999 (20\%), amelyek 83\%-a önálló vállalkozó, majd a 3. helyen a kisegítő családtagok 234.929 (7\%). A foglalkoztatott munkások 97\%-a teljes munkaidővel dolgozik, alacsony, azaz 3\%-a mindössze a részmunkaidős (part-time - nem teljes munkaidővel foglalkoztatottak) munkát végzők részaránya (ARS, 2009).

1. táblázat

A szerb aktív lakosság csoportositása iskolai végzettség és lakhely szerint, 2009

\begin{tabular}{lcc|ccccc|c}
\hline & & \multicolumn{3}{|c|}{ Alacsony } & & & \\
& & & Iskolai & iskolai & Középfokú & Felsőfokú & \\
Aktív lakosság & & & $\begin{array}{c}\text { végzettség } \\
\text { végzettség }\end{array}$ & végzettség & végzettség & urbán & rurális \\
megoszlása & összesen & $\%$ & nélk & $\%$ & $\%$ & $\%$ & $\%$ & $\%$ \\
\hline Aktív lakosság & 3.131 .280 & 100,0 & 0,9 & 23,2 & 58,2 & 17,7 & 55,7 & 44,3 \\
Foglalkoztatottak & 2.642 .686 & 84,4 & 1,0 & 23,9 & 56,3 & 18,8 & 53,8 & 46,2 \\
Munkanélküliek & 488.595 & 15,6 & 0,4 & 19,4 & 68,5 & 11,6 & 65,9 & 34,1 \\
\hline Forrás: $A R S, 2009$ & & & & & & & &
\end{tabular}

Forrás: ARS, 2009

${ }^{19}$ ARS - Anketa o radnoj snazi, 2009 
A szerb munkaképes lakosság foglalkoztatottsági rátája (51\%) Európai viszonylatban alacsony. ${ }^{20}$ A foglalkoztatottak 70\%-a 2009-ben magántulajdonnal rendelkező munkaadónál dolgozik, 27\%-ukat az állam foglalkoztatja, majd társadalmi és egyéb tulajdonformában tevékenykedik a foglalkoztatottak 3\%-a (ARS, 2009).

Kiemelve a munkanélküliek csoportját elsősorban, láthatjuk a középfokú végzettséggel rendelkezők óriási részarányát (68,5\%). Az elhelyezkedés nehézségeivel legkifejezettebben ez a népességcsoport szembesül (Arandarenko-Ognjenović, 2008). Az általuk képviselt munkaerő kínálat nem megfelelő. A szakoktatás reformjai, felnőttképzés, élethossziglani tanulás intézményesítése, versenyképes tudás, kompetencia szükséges (Gábrity Molnár, 2008c, ehhez kapcsolódóan Takács, 2008).

2. táblázat

A szerb aktív lakosság korcsoportok szerinti megoszlása, 2009

\begin{tabular}{lrcccccc}
\hline Életkor & & $15-24$ & $25-34$ & $35-44$ & $45-54$ & $55-64$ & $65+$ \\
\hline Foglalkoztatottak & 2.642 .686 & 5,5 & 21,3 & 24,2 & 27,7 & 15,4 & 5,9 \\
Munkanélküliek & 488.595 & 20,0 & 29,5 & 19,7 & 21,3 & 9,1 & 0,4 \\
\hline
\end{tabular}

Forrás: ARS, 2009

3. ábra

A szerb korcsoportokra bontott népesség aktivitási jellemzői, 2009

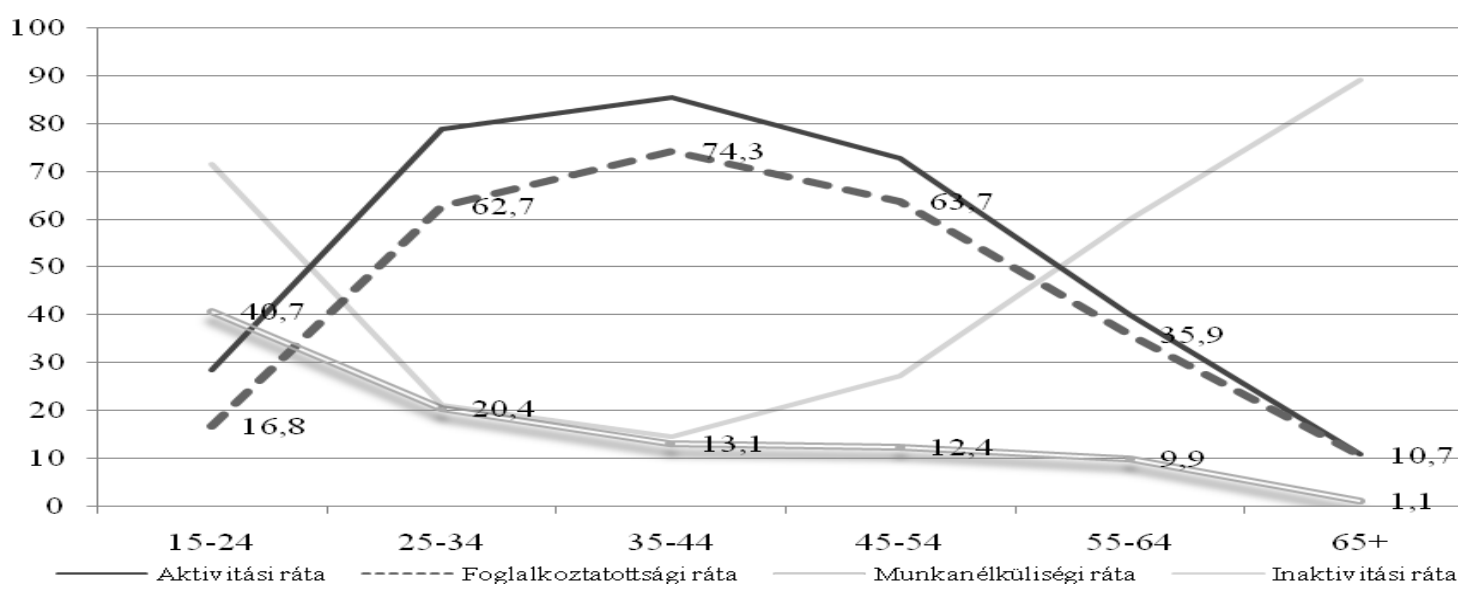

Forrás: ARS, 2009

\footnotetext{
${ }^{20}$ Eurostat adatok alapján a környező országok foglalkoztatottsági rátája 2009. júniusában a következő volt: EU27 65,9\%, EU25 66,3\%, EU15 67,3\%, Bulgária 64\%, Csehország 66,6\%, Magyarország 56,7\%, Ausztria $72,1 \%$, Románia 59\%, Szlovénia 68,6\%, Szlovákia 62,3\%, Horvátország 57,8\%. Ezzel szemben a munkanélküliség alakulása a környező országokban, 2009-ben a következő volt: EU27 8,9\%, EU25 9,1\%, EU15 9,1\%, Bulgária 6,5\%, Csehország 6,5\%, Magyarország 9,6\%, Ausztria 4,8\%, Románia 6,4\%, Szlovénia 6\%, Szlovákia 11,2\%, Horvátország 9,2\% (EUROSTAT, 2009).
} 
Az aktivitási és foglalkoztatási ráta Szerbiában a 15-24 éves korcsoport esetében alacsony, ez az iskoláztatás időszakának egybeesése miatt alakul így. Az 54. életévet követően az aktivitás hirtelen leesik, amely a nyugdíjaztatási törvénykezés feltételeit tükrözi.

A fiatalok között kifejezetten magas a munkanélküliség. A 34 éven aluli munkaképes lakosság a teljes munkanélküliek mintegy 50\%-át teszik ki. A munkanélküliek 36\%-a először keres munkát, 65\%-uk pedig az elhelyezkedésre 1-10 évet is vár, tömegesítve ezáltal a tartós munkanélküliséget. A munkanélküliek 10\%-a 1-2 hónapot vár az első munkába állásra, 12\%-uk 3-5 hónapot,13\%-uk pedig akár egy évet is vár az elhelyezkedésre. Nem tanúsít megfelelő szakmai, sem térbeli mobilitást a szerbiai munkaerő (ARS, 2009). Az összmunkanélküli területi megoszlásában élen jár Belgrád-körzet (13\%), majd a vajdasági dél-Bácskai körzet (9\%), illetve a Niš-i (7\%), Raška-i (7\%), és Šumadija-i (5\%) körzetek. (NSZZ, 2009).

A munkahely elvesztése 2009-ben a következő ágazatokban következett be legdrasztikusabban: feldolgozóipar 23\%, kereskedelem 23\%, oktatás 15\%, ingatlanügyek 9\%, építőipar 6\%, közlekedés és vendéglátóipar 4-4\%. Az okok között szerepel szerződéses viszony megszünése (55\%), közös megegyezés (19\%), egyéb okok (10\%), de a nyugdíjaztatás is, illetve technológiai fölösleggé válás (5\%) (NSZZ, 2009).

A Köztársasági Statisztikai Hivatal adatai alapján összegzett, a munkáltatók által megfogalmazott igények 70\%-a szakképzett munkaerőre irányul, míg 30\%-a szakképzetlenre. 72\%-ban meghatározott időre foglalkoztatnák a munkaerőt, míg az esetek 28\%-ában meghatározatlan időre szóló állásajánlatot képviselnek a munkaadók (NSZZ, 2009).

A munkanélkülieket a következő karakteres csoport határolja be:

- tartósan munkanélküliek,

- fiatalok, első munkát keresők,

- középiskolai végzettségüek,

- nem megfelelő képesítésekkel rendelkező munkaerő,

- a regionális különbségek miatt a fejletlen régiókban munkát keresők nagy részaránya,

- nem mobil munkaerö,

- a privatizáció során munkafelesleggé vált munkanélküliek, 
- a motiválatlan, érdektelen, szociális juttatásokból élő munkanélküliek (zsargonnal: zezaposleni, funemployed).

A fentiekben közölt statisztikai adatok a szerb statisztikai információs rendszer összehangolatlanságának problémájából adódóan a nemzeti statisztikai adatbázis két forrásból táplálkozik, egyrészt a Köztársasági Statisztikai Hivatal, illetve a Nemzeti Foglalkoztatásügyi Hivatal által gyüjtött adatokból.

\section{VAJDASÁG - A MUNKAERŐT ÉRINTŐ REGIONÁLIS EGYENLŐTLENSÉGEK}

Makro-regionális összehasonlításban a foglalkoztatási és munkanélküliségi mutatók minden téren kedvezőtlenebbek a tartományban (Đurđev, 2009). Fontos kiemelni azonban, hogy a gazdasági és politikai krízis éveit megelőzően a Vajdaság a munkaerő szempontjából az ország egyik legfejlettebb régiója volt (Szlávity, 2008).

A munkaerőpiac kereslet és kínálat oldalán megjelenő problémákat fokozzák az egyre kifejezettebb és növekvő regionális egyenlőtlenségek Szerbia szerte (ArandarenkoOgnjenović, 2008). Radić a munkaerőpiacot, foglalkoztatáspolitikát érintő aktuális problémák között a regionális egyenlőtlenségeket emeli ki (Radić, 2005a). A tranzíció folyamatai a regionális egyenlőtlenségeket felerősítette. Az egyes területek demográfiai, emberi erőforrásbeli hiányosságokat szenvedtek el, gazdasági és társadalmi hanyatlás vette kezdetét, erősödő szociális nyomásokkal. (Arandarenko-Nojković, 2007). Ugyanerre a problémára hívja fel a figyelmet tanulmányában Gábrity Molnár, amikor a vajdasági kistérségek közti munkanélküliségből adódó jelentős eltéréseket vizsgálja (Gábrity Molnár, 2006a).

A Vajdaság humánerőforrás-potenciálját elemezve Đurđev kiemeli a fiatal és idős lakossági kontingens kiegyenlítődését, valamint a férfiak számának folyamatos csökkenését a lakosság összetételében (Đurđev, 2009). A munkaképes lakosság foglalkoztatási rátája a Vajdaságban a férfiak esetében $70,8 \%$, nők esetében $50,7 \%$. A munkanélküliségi ráta a nők esetében 3,6\%-kal nagyobb, 15,9\% volt 2008-ban a Vajdaságban. A régió munkaképes lakosságának aktiviási rátája 2,2\%-kal alacsonyabb a Közép-szerbiai aktivitási rátától. A foglalkoztatottsági ráta a régióban 1,7\%-kal alacsonyabb, mint Közép-Szebiában. A munkanélküliség a Vajdaságban magasabb, mint Szerbiában, illetve Közép-Szerbiában, $15,8 \%$. 
3. táblázat

A foglalkoztatottsági mutatók regionális összehasonlítása

\begin{tabular}{lccc}
\hline & Vajdaság & Közép-Szerbia & Szerbia \\
\hline A munkaképes lakosság aktivitási rátája & $\mathbf{6 0 , 8 \%}$ & $63,0 \%$ & $62,7 \%$ \\
A munkaképes lakosság foglalkoztatottsági rátája & $\mathbf{5 2 , 2 \%}$ & $53,9 \%$ & $53,7 \%$ \\
\hline
\end{tabular}

Forrás: Đurđev, 2009.

4. ábra

A 15 évnél idösebb vajdasági lakosság munkanélküliségi, foglalkoztatottsági és aktivitási jellemzőinek alakulása 2005-2009 között

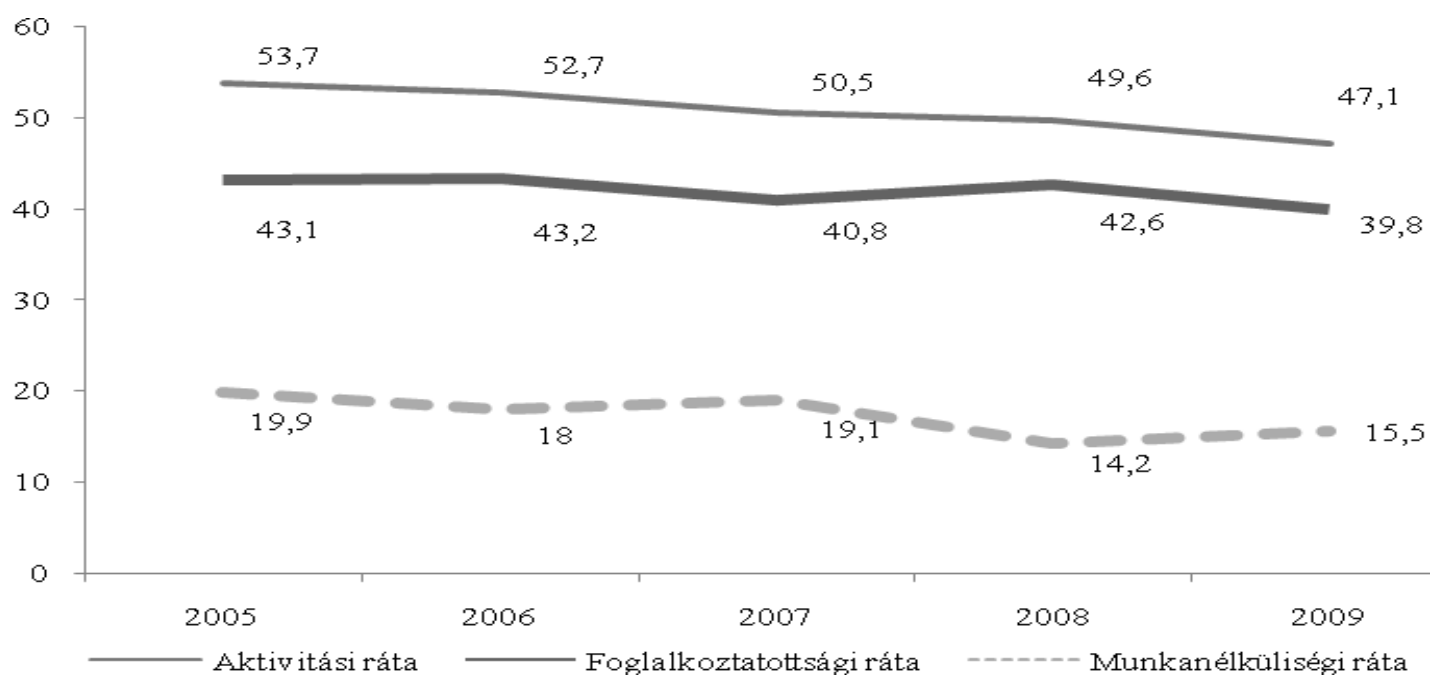

Forrás: CESS, 2009, ARS, 2009 alapján saját szerkesztés

A 2005-2009 közötti időszak adatait elemezve, láthatjuk, hogy a Vajdaságban visszaesés tapasztalható. A munkanélküliség nőtt, az aktivitási és foglalkoztatottsági ráta viszont csökkentek. Csökkentek továbbá az átlagos bérek is a Vajdaságban. 2007-2008 között az átlagos bérek valamivel erősebbek voltak a tartományban, mint Szerbiában, majd 2009-ben a szerbiai átlag alatt alakultak. Legmagasabb átlagbérek a következő 5 községben voltak: Beočin, Apatin, Újvidék, Versec, Pancsova (Sokić M., 2009).

A foglalkoztatottak összetételében domináns a foglalkoztatott munkások részaránya: 72,9\%, majd az önfoglalkoztatottak 22,7\%-a, és a háztartásbeliek 4,4\%-a. A foglalkoztatottak tulajdon szerinti összetételben, a magánosítás folyamatait követően 2008-ban a régió foglalkoztatottainak megoszlása: magán tulajdon 60,5\%, állami tulajdon 29,5\%, nem- 
bejegyzett magántulajdon 4,6\%, illetve (a még meglévő) társadalmi tulajdon 3,7\% (Đurđev, 2009). A fejlett országok tapasztalataival ellentétben a gazdasági ágak között dominál a mezőgazdasági foglalkoztatottak részaránya (erdészetet, vízgazdálkodást is beleértve) 23,3\%, majd a feldolgozóipar 21\%-kal, és a kereskedelemben 15,6\%-kal.

A tartományi Foglalkoztatás ügyi hivatal által képviselt vajdasági munkaerőpiaci kinálat jellemzői: nagyszámú, munkatapasztalat nélküli munkanélküli, a fiatalok és nők magas részaránya, első munkát keresők, gyakornokok, rokkantak, 50 év felettiek, menekültek magas részaránya (Šuljmanac-Šécerov - Durman, 2006). 2009-ben a munkanélküliek száma a tartományban 199.902. 12,4\%-ukat a 25-29 éves generáció képviselői alkotják. A munkanélküliek 26,7\%-a egy évig, 22,2\%-a akár két évig is vár a munkába állásra. Az átlagos munkába állási idő 48 hónap (Sokić M., 2009).

\section{A NEMZETI FOGLALKOZTATÁSPOLITIKA REGIONÁLIS VONATKOZÁSAI, REGIONÁLIS INTÉZMÉNYI HÁTTERE}

A szerb regionális fejlődés óriási regionális különbségekkel szembesül. Európában Szerbia egyedi mértékű regionális különbségeket képvisel. A fejlett és fejletlen községek viszonya 1 : 15-höz, körzetek esetében 1 : 7-hez (RFS, 2007), míg a körzetek közötti regionális munkanélküliségi ráta 1 : 3 (Arandarenko-Nojković, 2007). A lakosság 21\%-ának otthont adó főváros a lakosság 30\%-át foglalkoztatja, a feldolgozóiparban megtermelt GDP 26\%-át adja, és Szerbia magasan képzett szakembereinek több, mint fele él Belgrádban. Általánosságban, a régiók fejlettlenségének okai: infrastrukturális, szakképzett emberi tőke hiánya, vállalkozói hajlandóság/befektetések hiánya.

A Nemzeti Foglalkoztatási Stratégia 2005-2010 (a Regionális Fejlesztési Stratégiával összhangban (RFS, 2007)) előtérbe helyezi a regionális különbségek csökkentését, a gazdasági tevékenység serkentését, a nők foglalkoztatását, KKV-k támogatását, marginális csoportok, fiatalok és tartós munkanélküliek foglalkoztatását, új, flexibilis munkaformák bevezetését, stb. Egyik fontos elképzelés, hogy a régión belüli munkaerő-mobilitást kell serkenteni, mert azzal a régió munkaerőpiacának merev struktúrája válik kezelhetőbbé. Régión belül kell a munkát a munkáshoz közelebb hozni, és megalapozni a leépült térségek revitalizációját (NFS, 2005). A probléma multidiszciplináris megközelítésének ad hangot a nemzeti stratégia, ugyanis kihangsúlyozza a regionális politika legitimálásának szükségességét, a pénzügyi támogatások folytonosságát, az önkormányzatok hatalmának

\footnotetext{
${ }^{21}$ Nacionalna strategija zapošljavanja za period 2005-2010. 2005. NFS - Nemzeti Foglalkoztatási Stratégia
} 
erősítését - decentralizációt, a lokális érdekképviseletek közötti hatékony munkaerő piaci dialógus kialakítását, a fejletlen régiók aktív támogatási politika általi segítését (hitel, donáció, stb.) (NFS, 2005).

Ebböl is látszik, hogy a regionális szinteken megjelenő problémák megoldására kitűnő nemzetgazdasági stratégiai javaslatok születnek. Azonban a központi területirányítási és intézményrendszeri megoldások „fejlesztés-érzéketlennek” és cselekvésképtelennek bizonyulnak regionális szinteken.

A foglalkoztatás ügye a szerb központi hatalmi szervek, így elsősorban a:

- Gazdasági és Regionális Fejlesztési Minisztérium,

- Munkaügyi és Szociális Politikai Minisztérium,

- $\quad$ illetve részben az Ifjúságügyi és Sportminisztérium hatáskörébe tartozik. ${ }^{22}$

- A minisztériumi szervek munkáját kiegészítő Nemzeti Foglalkoztatásügyi Hivatal a munkaerő piaci változásokkal, munkanélküliséggel, átképzésekkel, stb. kapcsolatos gyakorlati teendőket látja el. Dekoncentrált hatalmi szerveiként a körzetek szintjén müködő hivatalok végzik a lokális-regionális foglalkoztatással-munkanélküliséggel kapcsolatos teendőket.

A Vajdaságban átruházott hatáskörök formájában - regionális szinten (is) érvényesül bizonyos szinten a foglalkoztatáspolitika eszköztára. ${ }^{23}$ A Tartományi Gazdasági Titkárság nem rendelkezik a Gazdasági és Regionális Fejlesztési Minisztériumhoz hasonlóan a foglalkoztatás-politika külön eszköztárával. A teljes regionális foglalkoztatáspolitika hordozója a Tartományi Munkaügyi, Foglalkoztatási és a Nemek egyenjogúságával foglalkozó Titkárság ${ }^{24}$, amely a regionális foglalkoztatáspolitika gyakorlati kivitelezője is egyben, ösztönzi a munkanélküliek újbóli elhelyezkedését, gyakornokok foglalkoztatását, a munkanélküliek mezőgazdasági gazdaság-bejegyzését, önfoglalkoztatást, stb. A programok többségében a központi hatalom által meghozott, majd delegált, a tartomány területére vonatkoztatott végrehajtási feladatokat tartalmazzák. Teljes jogi és forrásszabályozási

\footnotetext{
${ }^{22}$ Zakon o ministarstvima = Službeni Glasnik RS. Br. 65/08

3 A hatásköri törvény 65. és 66. szakasza értelmében, átruházott hatáskörök formájában a Vajdaság Autonóm Tartomány a saját területén szabályozza, koordinálja illetve „felügyeli a foglalkoztatáspolitikát”. Központi szerepet továbbra is a Nemzeti Foglalkoztatás ügyi Hivatal játszik, azzal, hogy egy regionális intézményen keresztül (Pokrajinska služba za zapošljavanje) történik a dekoncentrált fiókintézetek munkájának koordinálása, további önálló programok foganatosítása. Zakon o utvrđivanju nadležnosti Autonomne pokrajine Vojvodine = Službeni Glasnik RS. Br. 99/09.

${ }^{24}$ Pokrajinski Sekretarijat za rad, zapošljavanje i ravnopravnost polova: http://www.novisad.rs/content/pokrainski-sekretari-at-za-rad-zaposh-ava-e-i-ravnopravnost-polova-izvrshnog-ve-a-ap-vo-vod ～(Letöltve: 2010. január 28.)
} 
szabadságot nem élvez ez a tartományi szerv sem. A decentalizáció folytonossága azonban a siker egyik alapfeltétele (Šuljmanac-Šééerov - Durman, 2006). „A teljes gazdasági és társadalmi fejlődés feltétele kap támogatottságot a funkcionális decentralizáció által" (Arandarenko-Ognjenović, 2008). Đurđev szintén hangsúlyozza az aktiv foglalkoztatáspolitika és a decentralizáció jelentősségét (Đurđev, 2009).

A Szerb Regionális Fejlesztési Stratégiában foglaltak alapján minden régió (körzet) saját maga kell, hogy foglalkoztatáspolitikai eszköztárát, a régió területén jelentkező szükségletekhez idomítva „kreálja”, és hogy fejlessze a foglalkoztatás lehetőségeit és növelje a régió foglalkoztatottságát. Mindehhez azonban forrásszabályozási hatáskör hiányában, a meglévő, központi hatalmi szerveknél történő pályáztatási rendszer müködtetésével nincs lehetőség.

A reigonális foglalkoztatáspolitika tervezése során a munkanélküliek hatalmas tömegei miatt Gábrity Molnár kiemeli az ex post intézkedések szükségességét, ugyanakkor a jövendőbeli munkavállalókkal szemben a foglalkoztatáspolitika ex ante intézkedései szükségessek (karrierirodák, tanácsadás, felnőttképzés, stb.) (Gábrity Molnár, 2008c). A Nemzeti Foglalkoztatásügyi Hivatal munkájában aktív és passzív foglalkoztatáspolitikai intézkedések is jelen vannak. ${ }^{25}$ Fontos megemlíteni, hogy a Bruttó Hazai Termék 1\%-a körüli a foglalkoztatáspolitika általi ráfordítás. A Nemzeti Foglalkoztatásügyi Hivatal költségvetésében 92\% : 8\% arányban a passzív intézkedések dominálnak (viszont az össz aktív munkát keresők mindössze 7,6\%-a kap munkanélküliségi segélyt), amelyek nem hoznak hatékony eredményeket a foglalkoztatásban. Hiányzik a hivatal munkájában a monitoring bevezetése, és nagyobb hangsúlyt kell fektetni az aktív foglalkoztatás intézkedéseire, és a partnerség kiépítésére a foglalkoztatásban érdekelt intézmények között (iskolák, munkáltatók, munkvaállalók) (Arandarenko-Ognjenović, 2008, Gábrity Molnár, 2008b). Az egyes régiók lakosságának természetes (határon túli) mozgása (Vuksanović et al., 2004). közös foglalkoztatási problémák, országhatáron átívelő munkaerőpiaci és képzési rendszer kialakítását teszik szükségessé az „egységesülő európai térben” (Gábrity Molnár, 2008c, Arandarenko-Ognjenović, 2008).

\footnotetext{
${ }^{25}$ A tapasztalat azt mutatja, hogy az aktív ösztönzők (karrierépítés, képzések, állásbörzék, kiegészítő képzés, informatikai, nyelvi képzések, stb.) közül leghatásosabbak a kiegészítő képzések programjai voltak, ugyanis 43\%-os elhelyezkedés követte ezeket a programokat. Az önfoglalkoztatás, vállalkozásfejlesztés $70 \%$-os eredményességröl számoltak be (Arandarenko-Ognjenović, 2008).
} 
A munkanélküliség és foglalkoztatáspolitika regionális megközelítésére van szükség, mert a regionális különbségek folyamatosan növekszenek, a munkaerőpiac regionális intézményrendszerében és eszköztárában (adók, bérek, munkáltatói és szakszervezeti tárgyalások) viszont nincsenek differenciált, régió specifikus különbségek. Továbbá makrogazdasági szinten a munka, mint gazdasági erőforrás nem tud hatékonyan a fejlődés szolgálatába állni, ezért termelékenységcsökkenés, infláció is betudható ezeknek a regionális alapokon kialakuló - nemzetgazdasági szinten pedig cselekvésképtelenséggel fémjelezhető problémáknak.

\section{KÖVETKEZTETÉSEK}

Szerbia a tranzíció folyamataiban a munkaerő nagymértékü (szakmai, erkölcsi, anyagi) súlyvesztését tapasztalta meg. A munkanélküliség európai viszonylatban kifejezetten magas, a foglalkoztatottság ezzel ellenben alacsony. Nehéz helyzetben vannak a fiatalok, nők, nemzeti kisebbségek, fejletlen régiók lakói. Sok esetben emigráció követi a kilátástalan helyzetből való kilépés szándékát, illetve feketegazdasági üzérkedés - az egzisztenciális feltételek biztosítása érdekében. A munkaerő és foglalkoztatás a gazdaság legégetőbb problémájává váltak, strukturális problémák sokasága jellemzi a munkaerőpiacot. A központi hatalmi struktúrák nyomása folytán regionális-lokális cselekvésképtelenség lett úrrá az országban.

A regionális különbségeket megtapasztalva a szerb/vajdasági/regionális humántőke új érvényesülési feltételekkel szembesül. Kérdés: Mennyire tud a piaci gondolkodásmód az egyén, a munka, az oktatás világaiban teret hódítani? Hatékony megoldás mindenképp a foglalkoztatáspolitika regionális intézményrendszerének viszonyában keresendő, ahol stratégiai viselkedésformákra (és multiszektoriális megközelítésre) van szükség.

Cél: kompetens, versenyképes munkaerő biztosítása a régió számára! A hangsúly a régión (!) van, amely a nemzetgazdaság szerves része, de csak is decentralizált, legitim, regionális szintű intézményrendszeri, forrásszabályozási és érdekérvényesítési feltételek mellett tud gazdasági fejlesztésekre, versenyképességre, befektetetések-vonzására, a termelékenységre, gazdasági növekedésre, hatékonyságra, az átmeneti időszak és a reformok folyamatainak felgyorsítására, illetve végső (áhított) célként az EUs értékrendszer kiépítésére, EUs ambíciók megvalósulására koncentrálni.

A szakirodalmi feldolgozás elsősorban a szerb nyelven (illetve Szerbiában) megjelentetett irodalom áttekintését irányozta elő. Véleményem szerint, a témával behatóan foglalkozó, 
eredeti tudományos eredményekről beszámoló munka korlátozott mennyiségben áll rendelkezésre, régióspecifikus (empirikus) kutatásról nem is beszélve. Politikai és stratégiai dokumentumok foglalkoznak egyre többet a problémával, így a köztudatban főleg retorika szintjén a politikai elit képviseli ezt a témát.

A kutatás, szakirodalmi feldolgozás elején megfogalmazott felvetések a következőkben nyernek bizonyítást:

- A humántőke fejleszthetősége és fejlődése szempontjából a gazdasági és közigazgatási szubjektumok között nincs multiszektorális közelítés/közeledés, érdekegyeztetés, kommunikáció.

- A gazdasági és nemeztközi politikai térszekezet átalakulására a politikai elit néhány stratégiai dokumentum megírásával figyelmeztet (foglalkoztatási stratégia, a felnőttek képzésének stratégiája, migárciós stratégia, diszkrimináció megelőzése,stb.) általánosítva a problémát.

- A stratégiák gyakorlatba ültetése ez idáig nem történt meg, a központi hatalmi szervek által nem is lesz hosszútávon müködtethető.

- A regionális önszerveződés Szerbiában a munkaerő problémáira vonatkozólag nem funkcionál, annak ellenére, hogy nemzetgazdasági szinten is bizonyítást nyert, hogy a probléma a "központból” nem oldható meg. Delegálni feladatokat, ajánlásokat lehet, de a forrásallokáció játsza az igazán fontos szerepet.

- A központi hatalmi szervek a feladatokat és a felelősséget próbálják sok esetben decentralizálni, ugyanakkor a feladatok megoldásához szükséges illetékességek, források elmaradnak.

- A cselekvésképtelenségi vákuumban az egyének (mukavállalók, munkanélüliek) ad hoc. döntésekkel próbálnak alkalmazkodni a piac elvárásaihoz, ugyanis a piac elvárásait tudatos EUs és valós piacgazdasági elvek formálják át, amihez a gazdasági szubjektumok alkalmazkodni kényszerülnek.

- A piac és EU-s elvárásokhoz ugyanakkor nem alkalmazkodnak/nehezebben alkalmazkodnak például az oktatási intézmények, foglalkoztatásügyi hivatalok, költségvetési szervek.

- A humántőke fejlesztésében a gazdasági racionalitásra kell helyezni a hangsúlyt, függetlenül az intézményi - szektorközi párbeszédekben állástfoglaló intézmények aktuális fejlesztéspolitikai hitvallásától. 


\section{JAVASLATOK}

A regionális (tartományi) és lokális szinten rendelkezésre álló - a munkaerő fejlesztését elősegítő - térségfejlesztési megoldások alkalmazását javaslom:

- Tartományi hatáskörök érvényesítésével és a meglévő regionális hatalmi struktúrán belül, a meglévő tartományi intézményrendszerrel kell a problémákat megoldani.

- A konkrét és törvényes nemzeti területrendezési felosztásban a Vajdaság, mint NUTS 2 régió stratégiai tervezésére van szükség (a nemzeti stratégiai tervezés általánosított megközelítése nem elfogadható a régió számára).

- Regionális (tartományi) szinten a stratégiai tervezés során, az oktatási és foglalkoztatási igényeket és a gazdasági térszerkezet alakulását (határrégiók, szomszédos országok és EU) egészében kell figyelni. A munkaerő mobilitását szem előtt tartva kell kialakítani azt a társadalomgazdasági közeget, amelyben a humántőke versenyképes fejlődése, gazdasági sikere megvalósítható.

- Kerülendő a központi hatalom által ,regionális” szinten müködtetett dekoncentrált intézményi infrastruktúra és a delegált „minisztériumi megoldási javaslatok" támogatása. Ezek eddig sem bizonyultak hatékonynak.

- A lokális szint szerepe az igényfeltárásban, a munkáltatói vélemények elemzésében, illetve az érdekegyeztetések kezdeményezésében nyilvánul meg (empirikus kutatások végzése). Az önkormányzati együttmüködések, több önkormányzat egységes fellépése segítheti a probléma átfogóbb, kiterjedtebb felülvizsgálatát.

- A jövőben (a regionális fejlesztési törvény gyakorlatba ültetését, illetve a régiók, térségek lehatárolását követően) a helyi önkormányzatok által kialakított térségek (NUTS 3), mint kisebb területi egységek kell, hogy elvégezzék ezeket az igényfelméréseket. Ezek a térségfejlesztési egységek a legitim hatalmukon keresztül (intézményi forma - bejegyzett piaci gazdasági szubjektum) rendelkezhetnek a regionális térségfejlesztés külső forrásai feletti felügyelettel is, tehát a pénzlehívási lehetőségeiket (EU-s alapok) ügyességük, szakmai rátermettségük fogja meghatározni.

- A letisztázott hatalmi viszonyok megalapozásával, a stratégiai tervezés szakmai megalapozottságával kaphatnak csak helyet az alulról induló regionális 
önszerveződés kezdeményezései. A regionális önszerveződés sikere már a régió érdekhordozóinak (iskolák, önkormányzatok, regionális ügynökségek, a gazdasági racionalitást, piaci magatartást képviselő gazdasági szubjektumok) együttmüködésétől, szorgalmától, hozzáértésétől függhet csak.

\section{Olyan - az aktív foglalkoztatáspolitikai (regionális) eszköztárának jelentőségét} pontosító regionális foglalkoztatási stratégia kidolgozása szükséges, amelyben:

- a felnőttképzés intézményi szabályozása, hosszú távú céljai fogalmazódnak meg,

- biztosítva a versenyképes tudás-kitermelését a régióban,

- illetve a gazdasági szerkezetváltás során és a gazdasági térszerkezet folyamatos változása miatt megjelenő új munkaerő-és profiligények, és a munkanélküliség problémáját is hatékonyan kezeli,

- továbbá növelni kell az emberi töke értékét, amely alapot kell, hogy szolgáltasson az ország fenntartható társadalom-gazdasági fejlődéséhez, regionális és globális integrálódásához,

- lehetővé kell tenni az egyének számára a társadalomban való teljes részvételt,

- az egyenlő elhelyezkedést,

- biztosítani kell a munkaerő versenyképességét,

- foglalkoztatási mobilitást,

- rugalmasságot,

- esélyegyenlőséget.

\section{IRODALOMJEGYZÉK}

ARANDARENKO, M. - NOJKOVIĆ, A. 2007: Pregled tržišta rada u Srbiji. h.n., AENEADS.

ARANDARENKO, M. - OGNJENOVIĆ, K. (szerk.) 2008: Reforma tržišta rada u Srbiji i Slovačkoj. Beograd: Ineko.

ARS 2009: Anketa o radnoj snazi. Saopštenje br. 155. Republički zavod za statistiku.

BALON, B. 2007: Rodno senzitivna statistika kao neophodan element u demokratizaciji društva $=79-95$. .

BOŽANIĆ, D. et al. (szerk.) 2007: Žene $i$ muškarci u Vojvodini. Izveštaj o rodnoj ravnopravnosti od 2004. do 2006. godine. Novi Sad, Pokrajinski sekretarijat za rad, zapošljavanje i ravnopravnost polova.

BOŽIĆ, M. 2005: Nezaposlenost radne snage - uzrok i posledica procesa tranzicije na Balkanu. Komunikacija. Beograd. Letöltve: 
http://www.komunikacija.org.rs/komunikacija/knjige/index_html/knjiga19/pdf24.pdf (200911-20)

DOMAZET, I. - ZUBOVIĆ, J. 2009: Uticaj tranzicije na zaposlenost i zarade u Srbiji. Ekonomski Fakultet, Beograd. Letöltve:

http://www.ekof.bg.ac.yu/centri/nde/2009/01/Domazet_Zubovic.pdf (2009-11-20)

ĐURĐEV, B. 2009: Ljudski resursi u Vojvodini = CESS Magazin. 16-17. sz. 18-21. o.

EUROSTAT, 2009: http://epp.eurostat.ec.europa.eu/portal/page/portal/statistics/themes

GABRIĆ MOLNAR, I. 2000: Obrazovni sistem - osnov raslojavanja i artikulisanja ljudskog potencijala. In: KALINIĆ, V. (szerk.): Anali ekonomskog fakulteta u Subotici. Broj 5. Szabadka, Szabadkai Közgazdasági Kar. 91-97. o.

GÁBRITY MOLNÁR IRÉN 2006a: Munkaerőpiac. In: GÁBRITY MOLNÁR IRÉN RICZ ANDRÁS (szerk.): Kistérségek életereje - Délvidéki fejlesztési lehetöségek. Szabadka, Regionális Tudományi Társaság. 83-94. o.

GÁBRITY MOLNÁR IRÉN 2006b: Migrációs folyamatok. In: GÁBRITY MOLNÁR IRÉN - RICZ ANDRÁS (szerk.): Kistérségek életereje - Délvidéki fejlesztési lehetőségek. Szabadka, Regionális Tudományi Társaság. 69-72. o.

GÁBRITY MOLNÁR IRÉN 2008a: A szerbiai emigráció fél évszázada. „Határtalan határok” jubileumi Nemzetközi Földrajzi Konferencia, Dobogókő. http://gabritymolnariren.com/emigracio.pdf (2009. november 15.)

GÁBRITY MOLNÁR IRÉN 2008b: A régió felnőttoktatási rendszerének jellegzetességei. In: GÁBRITY MOLNÁR IRÉN (szerk.): Képzetteké a jövő. A felnőttképzés háttere ÉszakBácska iskolahálózatában. Szabadka, Regionális Tudományi Társaság. 31-108. o.

GÁBRITY MOLNÁR IRÉN 2008c: Munkaerőpiaci elemzések. In: BARLAI JENÖ GÁBRITY MOLNÁR IRÉN (szerk.): Hazaérsz. Esély és esélyegyenlöség a Vajdaságban. Szabadka, Vajdasági Módszertani Központ. 69-85. o.

GÁBRITY MOLNÁR IRÉN 2009a: Képzési igények és kínálatok térszerkezete. In: SOMOGYI SÁNDOR (szerk.): A Regionális Tudományi Társaság Évkönyve 2008. Szabadka, Regionális Tudományi Társaság. 223-248. o.

GÁBRITY MOLNÁR IRÉN 2009b: Magyar közoktatási intézmények részvétele a vajdasági felnőttoktatásban. In: SARNYAI KÁROLY (szerk.): Esélyt adó felnőttképzés. Magyarkanizsa, Cnesa Oktatási Müvelődési Intézet. 21-32. o.

GREČIĆ, V. 2001: Migracije sa prostora SR Jugoslavije od početka 90-tih godina XX veka. = Ekonomski anali. 44. évf. 153-154. sz. 57-84. o.

GREDELJ, S. 2006: Virtuelni povratak ,četvrte“ i „pete“ generacije migranata. = Filozofija i društvo. 29. sz. 77-88. o.

KINCSES ÁRON - TAKÁCS ZOLTÁN 2010: Szerb állampolgárok Magyarországon. (Kézirat megjelenés alatt).

LAKI, L - GABRIĆ MOLNAR, I - KOVAČ ŽNIDERŠIČ, R 1997: Sociologija za ekonomiste. Subotica, Ekonomski fakultet Subotica.

MARJANOVIĆ, G. 2002: Nezaposlenost i tržište rada u privredi SR Jugoslavije = Ekonomske teme. 40. évf. 4. sz. 149-156. o. 
MARKOVIĆ, Ž. D. 2009: Globalna ekonomija i ljudski faktor = Pedagogija. 64. évf. 1. sz. 68-79. o.

MIHAILOVIĆ, S. 2004: Oduzimanje budućnosti - Omladina Srbije u vodama tranzicije. In: SREĆKO, M. (ed.): Mladi zagubljeni u tranziciji. Beograd, Centar za proučavanje alternativa. 17-37. o.

NAGY IMRE 2007 (szerk.): Vajdaság. Pécs - Budapest, Dialóg Campus Kiadó.

Nacionalna strategija zapošljavanja za period 2005-2010, 2005. Ministarstvo rada, zapošljavanja i socijalne politike. Beograd.

(http://www.zavodsz.gov.rs/PDF/Nacionalna\%20strategija\%20zaposljavanja.pdf , Letöltve: 2010.01.31.)

NÉMETH SZILVIA 2005: Élethossziglani tanulás az Európai Unió dokumentumainak tükrében. In: PAPP Z. ATTILA (szerk.): Kihasználatlanul: A romániai (magyar) felnöttképzés rendszere. http://adatbank.transindex.ro/vendeg/htmlk/pdf3632.pdf 14-32. o.

NSZZ 2009: Nezaposlenost $i$ zapošljavanje u Republici Srbiji. Saopštenje br. 85. Nacionalna služba za zapošljavanje.

PAVLICA, B. 2005: Migracije iz Jugoslavije u Nemačku - migranti, emigranti, izbeglice, azilanti. = Međunarodni problemi. 57. évf. 1-2. sz. 121-158. o.

PEJIĆ, R. 2005: Poslodavci traže kompletne ličnosti = Obrazovanje i Razvoj 1. Évf. 3. sz. 10- 11.o.

Pokrajinski Sekretarijat za rad, zapošljavanje i ravnopravnost polova: http://www.novisad.rs/content/pokra-inski-sekretari-at-za-rad-zaposh-ava-e-i-

ravnopravnost-polova-izvrshnog-ve-a-ap-vo-vod (Letöltve: 2010. január 28.)

Popis 2002. Beograd, Republički zavod za statistiku Srbije.

RADIĆ, J. 2005a: Politika tržišta rada i strategija zapošljavanja = Privredna izgradnja. 48. évf. 1-2. sz. 81-92. o.

RADIĆ, J. 2005b: Socijalna dimenzija integracionih procesa u Evropi = Ekonomske teme. 43. évf. 2. sz. 441-446. o.

Republički zavod za statistiku Srbije 2008: Žene i muškarci u Srbiji, Beograd.

ŠEĆIBOVIĆ, R. 2005: Balkanski nemiri = Obrazovanje $i$ Razvoj 1. Évf. 3. sz. 3. o.

ŠULJMANAC-ŠEĆEROV, M. - DURMAN, D. 2006: Zapošljavanje i zaposlenost u Vojvodini i kretanje na tržištu rada. = Zbornik Matice srpske za društvene nauke. $121 \mathrm{sz}$. 503-512. o.

SAVIĆ, M. 2008: Potencijalni pravci migracija tipa grad-grad u Vojvodini. = Stanovništvo. 46. évf. 2. sz. 63-80. o.

SZLÁVITY ÁGNES 2008: Állásvadász. Kézikönyv diplomás pályakezdőknek. Szabadka, Vajdasági Módszertani Központ.

SOKIĆ, M. et al. (szerk.) 2009: AP Vojvodina. Socio-ekonomski profil. Novi Sad, Vojvodina - CESS.

SOKIĆ, S. 2008: Teorijska zasnovanost tržišta rada = Godišnjak 2008. Univerzitet u Beogradu. Fakultet političkih nauka. 2. évf. 2. sz. 429-444. o. 
STOJIĆ ATANASOV, G. 2004: Changes is the labour market - European Union and Serbia = Philosophy, Sociology and Psychology. 3. évf. 1. sz. 17-31. o.

Strategije unapređenja položaja osoba sa invaliditetom u Republici Srbiji http://www.region.vojvodina.gov.rs/images/stories/strategije/Strategija\%20unapredjenja\%2 0polozaja\%20osoba\%20sa\%20invaliditetom\%20u\%20Republici\%20Srbiji.pdf (Letöltve: 2010.01.31.)

Strategija regionalnog razvoja Srbije za period od 2007 do 2012. godine (2007) = http://www.merr.sr.gov.yu/sektori/rrpolitika.php?lang=lat (2007. 03.01.)

Strategija za upravljanje migracijama = Službeni Glasnik RS. Br. 59/2009.

TAKÁCS ZOLTÁN 2008: A munkaerő-kompetencia és az oktatás viszonya. In: GÁBRITY MOLNÁR IRÉN - MIRNICS ZSUZSA (szerk.): Regionális erőnlét - a humánerőforrás befolyása Vajdaságban. Szabadka, Magyarságkutató Tudományos Társaság. 267-292. o.

VUKSANOVIĆ, G. - ĐURĐEV, B. - IVKOV, A. 2004: The Province of Vojvodina in the Vicinity of EU Regions. A General Comparison of Human Resources with the Emphasis on (Un)employment. = Geographica Pannonica. 8. sz. 29-32. o.

Zakon o ministarstvima = Službeni Glasnik RS. Br. 65/08

Zakona o sprečavanju diskriminacije osoba sa invaliditetom = Službeni Glasnik RS. Br. $33 / 06$

Zakon o utvrđivanju nadležnosti Autonomne pokrajine Vojvodine = Službeni Glasnik RS . Br. 99/09.

ZJALIĆ, M. LJ. 2009: Ljudski resursi i njihova osposobljenost za uključivanje u razvoj privrede i društva = Međunarodni problemi. 61. évf. 1-2.sz. 92-111. o.

Zakon o profesionalnoj rehabilitaciji i zapošljavanju osoba sa invaliditetom = Službeni Glasnik RS. Br. 36/09 